Utah State University

DigitalCommons@USU

$5-1952$

\title{
Some Effects of Fluctuating and Falling Water Levels on Waterfowl Production
}

Kenneth E. Wolf

Utah State University

Follow this and additional works at: https://digitalcommons.usu.edu/etd

Part of the Environmental Sciences Commons

\section{Recommended Citation}

Wolf, Kenneth E., "Some Effects of Fluctuating and Falling Water Levels on Waterfowl Production" (1952). All Graduate Theses and Dissertations. 6251.

https://digitalcommons.usu.edu/etd/6251

This Thesis is brought to you for free and open access by the Graduate Studies at DigitalCommons@USU. It has been accepted for inclusion in All Graduate Theses and Dissertations by an authorized administrator of DigitalCommons@USU. For more information, please contact digitalcommons@usu.edu.

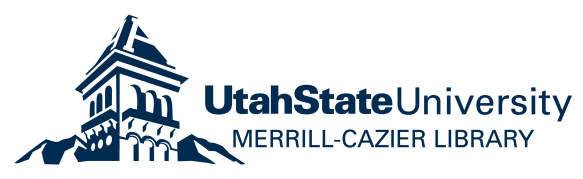




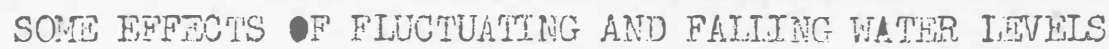
ON WATERTOWL PRODUETION

\section{by}

Kenmeth E. Wols

\section{A Thesis subutited in partial fulpjilntent of the reouirente for the degree of \\ rastor of scienco}

in

vild dife nenaganent

Utah State Agricultural. College

1.952

$$
\begin{aligned}
& 398.35 \\
& W 831
\end{aligned}
$$




\section{ACKNOWLEDGMENTS}

I am deeply grateful for the guidance and assistance of many people. Without their unselfish efforts, this study would have been vastly more difficult, prolonged, and perhaps even impossible.

Dr. Jessop B. Low, Leader, Wildlife Research Unit, guided and assisted many of the efforts throughout the course of the study and gave advice and constructive criticism in the preparation of the manuscript. My wife, Betty, helped in innumerable ways during the study, particularly in organizing, preparing and typing this manuscript. Professor A. H. Holmgren identified and verified plant species encountered in the study. Mr. Louis Klein built the sampling rings used in the plant collecting. John Conder and Herman Green assisted in the field, collecting some of the seed and plant samples.

I am especially indebted to the Wildlife Managenent Institute for the special grant which they made for the purpose of performing this study。 


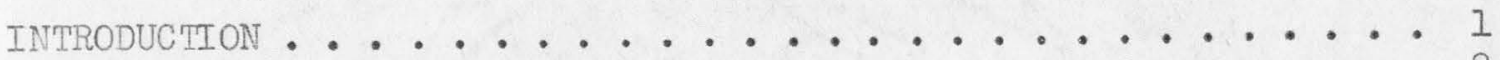
REVIEN OF IITERATURE ...................... 2 OBJECTIVES ....................... . . 3 LOCATIONS. . . . . . . . . . . . . . . . . . 3 TECHNIQUES ................... 6 NESTING STUDY. . . . . . . . . . . . . . ...... 8 Description of Study Areas................ 8 Nesting Density ....... . . . . . . . . . . . . 9 Nesting Production. . . . . . . . . . . . . . . 9 General...................... 9 Mortality Factors. ............... 17 Predation ........................ 17 Social Parasitism .............. 21 Unknown Causes. ............... 21 Water As a Mortality Factor ........... 21 Coot Nesting As Affected by Water Level Fluctuations ............ 22

Grebe Nesting as Affected by Water Level Fluctuations ......... 23

Duck Nesting as Affected by Water

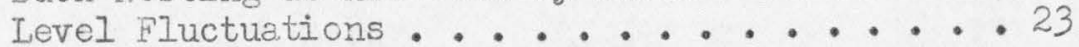
Buoyancy of Nest Materials. . . . . 25 Degree of Tolerance by Waterfowl to Water Level Fluctuations ......... 25 BROOD SURVIVAL . . .................... 27 General ..................... 27 Swan Lake Brood Data. . . . . . . . . . . . . 27 Newton Reservoir Brood Data............ 28 Cutler Reservoir Brood Data . . . . . . . . . . . 31 WATERFONL FOOD PRODUCTTON..................... 32

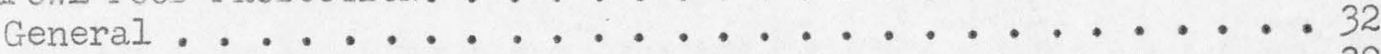

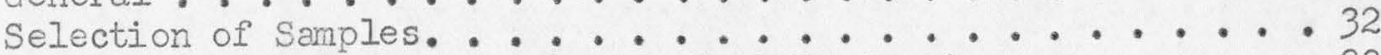
Qualitative Differences in Food Plant Production....... 33 Quantitative Differences in Food Plant Production. . . . . . . 33 Effect of Fluctuating and Dropping Water Levels . . . . . . 35 MANAGGVINT IMPIICATION ............................ 37 CONCLUSIONS . . . . . . . . . . . . . . 38 SUMMARY. . . . . . . . . . . . . . . . 38

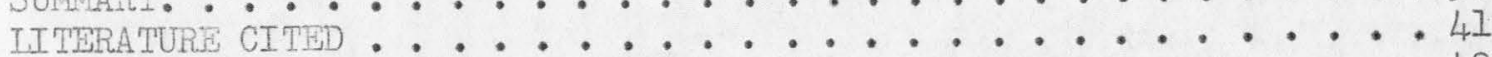

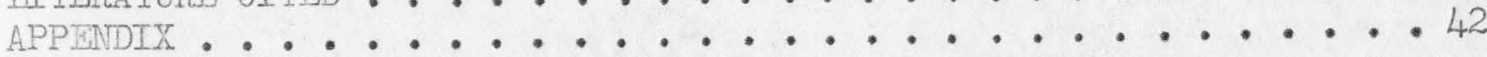




\section{IIST OF TABITS}

Table

1. A Comparison of the Nesting Fopulations of the Cache Valley Study Areas, 1951 . . . . . . . . . . . 12

2. Summary of Swan Lake Nest Histories, 1951......... . I8

3. Summary of Cutler Reservoir Nest Histories, 1951.... . . 19

4. Summary of Newton Reservoir Nest Histories, 1951 . . . . . 20

5. A Comparison of Brood Survival by Age Class - Cache Valley, Utah and Idaho, $1951 . . . . . . . .29$

6. A comparison of Average Sizes of Waterfowl Broods from Swan Lake, Newton and Cutler Reservoirs, 1951 . . . . 30

7. A Comparison of the Relative Abundance of Selected Plants from Swan Iake, Newton and Cutler Reservoirs in $1951 . . .34$

8. A Comparison of Waterfowl Food Production in 1951 on Swan Lake, Newton and Cutler Reservoirs ........ 36

\section{Appendix}

1. Swan Lake Water Levels in Feet Above Mean Sea Level. ... . 43

2. Newton Reservoir water Levels in Feet Above Mean

Sea Level. . . . . . . . . . . . . . 44

3. Cutler Reservoir Water Levels in Feet Above Mean

Sea Level 1951... . . . . . . . . . . 45

4. Cutler Reservoir Water Levels in Feet Above Mean

Sea Level 1951 . . . . . . . . . . . . 46

5. A Iist of Scientific Names for Waterfowl . . . . . . . 47 


\section{INTRODUCTION}

There are today many areas and types of water storage. The uses to which these are put are many, and the prospect for the future can only be that there will be an increase in the number of these reservoirs. These areas are usually operated with regard only for power production, irrigation, or storage, but there is a growing concern about the effects on wildlife which this type of operation may have. Fluctuating water levels, and falling water levels are not restricted to man-made impoundments but are characteristic of many of them. Biologists have observed that these variations in water levels are often harmful to some forms of wildlife. Fluctuating water levels generally were found to cause damage to waterfowl nests. The amount of damage, the amount of water rise and the time involved are values which have generally remai ned unknown, largely perhaps because some other aspects was of greater importance in the nesting studies.

There is a descending scale of values which have been placed on natural resources, and it is generally agreed that the waterfowl concerned would rank below the value derived from the impounded waters. Where it is practical, the management of these impoundments should take wildlife into consideration.

To have intentions of good management is not sufficient to effect conservation; these intentions must be implemented with the proper tools. This study was designed to discover magnitudes of cause and effect, and perhaps it will point the way to a more efficient utilization of associated resources. It was possible that the results of this study would show that there was little damage to waterfowl. On the other hand, if significant damage were to be discovered, contributing causes could be more closely delimited and so point the way toward corrective measures. 
Many waterfowl investigators have found evidence of damage by water to waterfowl nests; some have determined the amount of damage caused. Craighead and Craighead (1949) found that 25 per cent of a season's goose nests were destroyed by flooding. Williams and Marshall (1938) cited similar percentages for several species of ducks. As far as is known, there is no published work in which there is set forth specific causal factors. This is probably because of the fact that the extent of the water damage was determined as a secondary consideration or associated factor in general nesting studies.

In addition to direct damage, unfavorable water conditions have been found to exert profound indirect effects on waterfowl. Martin and Uhler (1939) state, "No single factor is more potent in preventing the development of waterfowl feeding grounds than extreme or irregular fluctuations." Wiebe (1946) cites the effects of water levels on waterfowl food plants as does Anderson (194I), Bellrose and Brown (194I), and Low and Bellrose $(1944)$.

Most of the investigations concerning waterfowl and waterlevels have been concerned with flooding and fluctuations on man-made impoundments, but Williams and Marshall (1937) found that sustained high winds over a period of some hours could effect a pile up of water in vegetation which would flood duck nests under natural habitat conditions.

Indirect effects on waterfowl by flooding and fluctuating waterlevels are generally brought about by direct effects on the plant community. Silting, high turbidities, agitation and other ecological factors have been found to be primary causes.

With a single exception (Wiebe and Hess, 1944) the problem of formulating management plans to alleviate or reduce the undesirable effects of fluctuating water levels has been relatively untouched. It is true that in many instances other considerations preclude the possibility of considering wildlife and particularly waterfowl, but other than an approach towards stabilization of levels there is little that can be done at present.

It is hoped that the findings of this study will serve to further implement what Wiebe and Hess have temed "water level managenent", and to furnish a basis for new managenent in the form of regulating fluctuation rate and extent. 


\section{OBJECTIVES}

This study was primarily a comparison of waterfowl production on areas with characteristically different water-level stabilities. The field work was divided into three phases. (1) A nesting study was made for the purpose of determining whether or not fluctuating or falling water levels affected waterfowl hatching success. This was intended to measure the magnitude and determine causal factors if damage was found.

(2) A brood survival study was followed on the different areas. (3) Investigations were made to determine whether or not there were qualitative and quantitative differences in submergent and emergent waterfow 1 food plants that grew on areas of different water level stability.

\section{LOCATIONS}

All areas studied were located in Cache Valley, a valley which lies for the greater part in northern Cache County, Utah, but also extends into Franklin and Bannock Counties of Southern Idaho. Three areas were included in the study, (1) an area of stable water levels, (2) one of fluctuating water levels, (3) an area of falling water levels.

Briefly, the areas may be described as follows:

(1) Swan Lake, a natural body of water which is located at the southern end of Bannock County, Idaho, was chosen as the control area. There was a limited utilization of its waters for irrigation purposes but the water level remained relatively stable (Figure 1). Of the few natural bodies of water in the valley, this lake was the best suited for a control. It is fed by a stream, springs, and drainage water from the marsh to the north; these effected a slow movement of water through the lake.

(2) Newton Reservoir is a 5,500 acre-feet irrigation impoundment located about $18 \mathrm{miles}$ north-north west of Logan, Utah. It was built by the Bureau of Reclamation and completed in 1946. It is a narrow canyon reservoir with steeply sloping shores (Figure 2).

Figure 2. A portion of Newton Reservoir showing the characteristic steep shore and the fringe of willow near the high-water mark.

During the months of April and May, Newton Reservoir water levels remained fairly stable, but during the first part of June water use began and the levels dropped abrubtly and steadily thereafter (Figure 3).

(3) Cutler Reservoir resulted from the construction of Cutler Dam by private hydro-electric power interests in 1927. It has since changed ownership but remains a commercial hydro-electric and irrigation project. The two areas chosen for study were located near the upper end of the impounded water. 


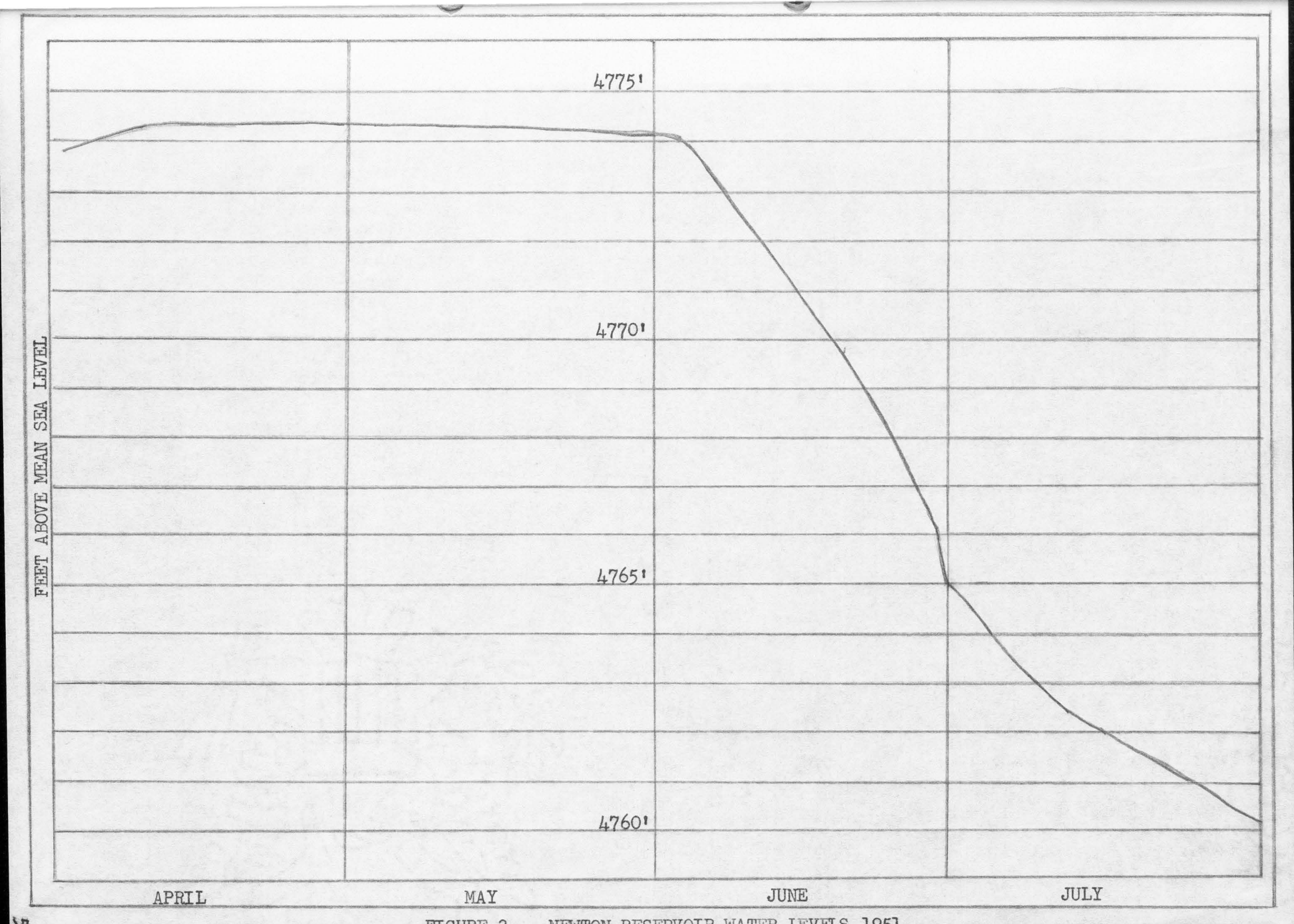


Cutler reservoir was subject to greatly fluctuating water levels which show little or no regularity in their occurrence. Run-off from the contributing Logan, Blacksmith Fork, Little Bear and Bear rivers, irrigation and hydro-electric drawdowns brought about maximum changes of as much as three feet in three days (Figure 4 ).

The water levels for the same period of preceeding years for which relatively complete records were available have been shown in Appendix Figure 1. Great irregularity characterizes all the periods shown.

\section{TECHNIQUES}

Appendix Figure 2 is a copy of the nest history form which was used in this study. The usual procedures were used to locate and mark nests. Early in the study it was found that some ducks built up their nests when the water rose. It was evident that some method was needed to fix the various egg levels which resulted in order to measure the amount of added material. The central stem of cattail (Typha sp.) was inserted in the nest at the bottom of the lowest eggs. On succeeding visits additional markers were inserted whenever changes were noted. This method was valuable because the stems did not contrast with nest materials, and they were sufficiently durable to withstand long soaking without becoming limp.

In addition to water depth data collected when the nests were visited, gage readings for the three areas were taken or obtained. A stake gage was installed at Swan Lake and read on the occasion of each visit. The U. S. Geological Survey maintains a recording gage at Cache Junction, Utah, which is approximately the geographic center of Cutler reservoir. The $U$. S. Bureau of Reclamation records periodic readings of the Newton Reservoir water levels. Both the Cutler and Newton reservoir records were obtained when the field work was terminated.

These readings were converted to elevations above mean sea level and will be found as Appendix Tables 1 through 4.

The graphs of water levels which have been given in Figures 1, 3, 4, and Appendix Figure 1 were prepared from these standardized gage readings.

Waterfowl food plants from all areas were collected on the basis of random plots from relatively comparable sites. Meter and tenth-meter samples were taken. For this purpose, strips of aluminum alloy, (spec. $24-S-1$ ), four inches wide and .065 inches thick were preformed and riveted to form circles of one meter and a tenth of a meter in area. Backing plates of the same material were used at the joints. The stiff spring quality of this alloy was admirably adapted to retaining the circular shape. The forms withstood a considerable amount of rough handling without being distorted.

The collecting submergent species, the forms were firmly pressed down into the vegetation, and a long, sharp knife was drawn around the metal to sever roots and branches that extended beyond the form. The vegetation 


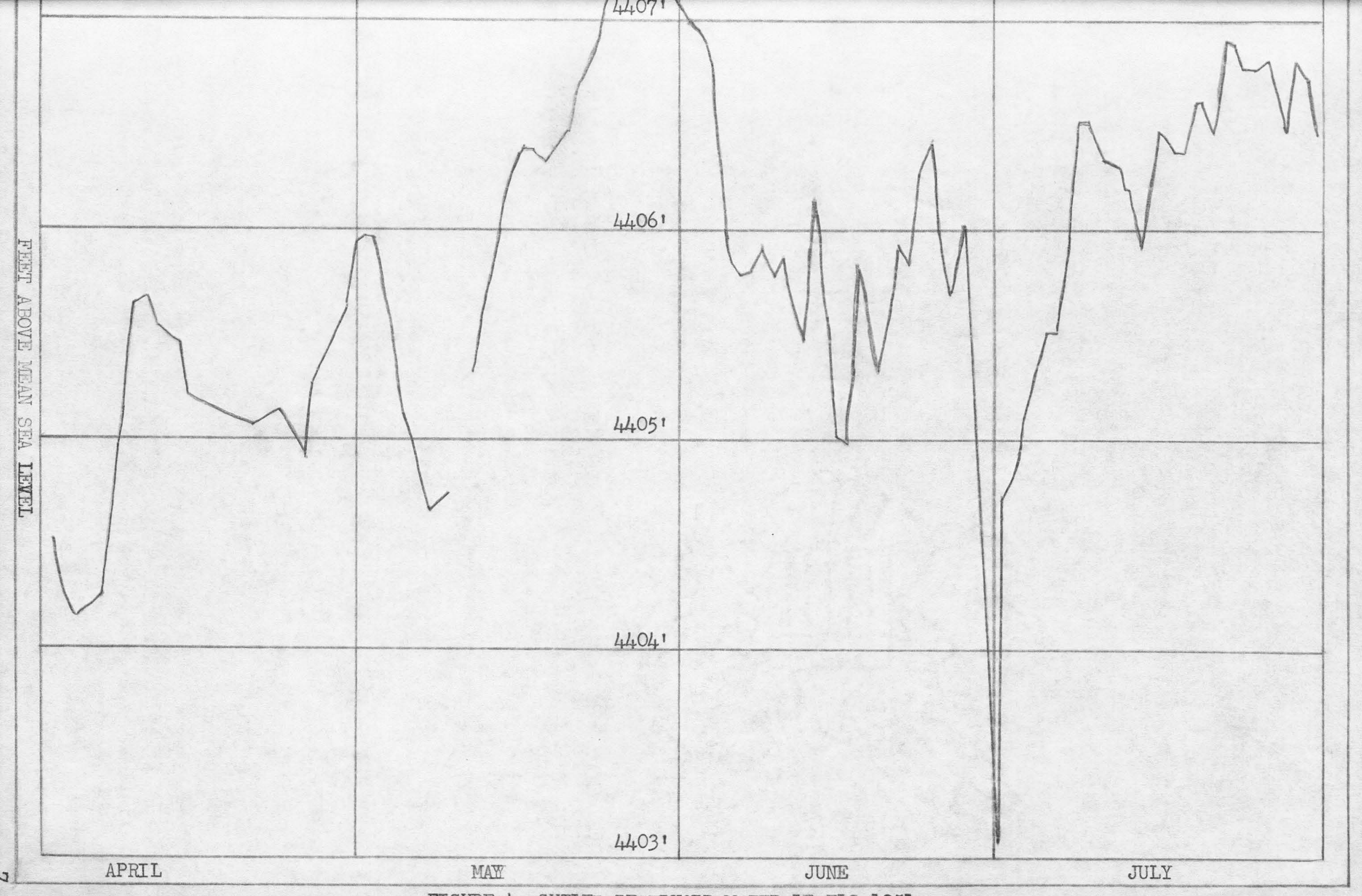


within the circle was carefully removed and washed in a bucket made of $3 / 16$ inch hardware cloth. Fxcess water was removed by whirling the container at the end of a short cord.

When thoroughly air dried, seed-bearing plants were threshed, fanned and screened to remove chaff, stems and other unwanted materials. Weight and volume determination were then made. Weight and volume of the total plant material was determined for submergent species.

Aerial photographs in the scale of 1 inch to approximately 400 feet were used in a.11 cover mapping, nest locating, and area measurements. Significant errors in scale were found when known reference points were checked. Correction factors had to be determined and used in all computations.

\section{NESTING STUDY}

\section{DESCRIPTION OF STUDY AREAS}

Two samples of Cutler Reservoir were selected for this study. The choice of these samples was somewhat limited, because cultivation, subjected to intensive grazing, or otherwise unsuited for nesting waterfowl. An area of about 98 acres was selected at the southern end of the reservoir. For convenience, this was termed the Cutler Area No. 1. Three miles north another area - about 77 acres - was selected. This was termed the Cutler Area No. 2.

Area No. I presented the conditions of grazed saltgrass and (Distichlia stricta (Torr.) Rybd.) sedge (Carex sp. and Eleocharis sp.) meadows gradualIy merging into a bulrush-cattail (Scirpus sp. - Typha sp. ) marsh which bordered and extended into the waters of the reservoir. Cutler Area No. 2 adjoined lands which were entirely devoted to dry-land grain farming. Broad shallows studded with islets of emergent vegetation and an occasional island of a more determinable outline characterized the area (Figure 5).

Swan Lake is bordered by a bulmush-cattail marsh. The west side strip of emergent vegetation was very narrow and a butte largely covered with sagebrush (Artemesia tridentata, Nutt.) rose abrubtly along much of its length. Sedge (Carex sp. and Eleocharis sp.) and grass meadows bordered the ends and much of the east side. The area selected for study measured about 68.5 acres.

Figure 5 Part of Area No. 1 of the Cutler Reservoir. Broad shallows dotted with islets of emergent vegetation are typical of much of the upper Cutler Reservoir. The abandoned railroad embankment is visible in the background. 
Newton Reservoir is situated in an agricultural area which is largely devoted to dry-land grain farming. Little habitat suitable for nesting waterfowl was present. A thin fringe of willow (Salix sp.) borders most of reservoir, and a small seasonal marsh was found at the southern end near the dam. Because of the unfenced grain fields, cattle were not grazed near the reservoir. There were few waterfowl found on the area, and the importance of this area in the study was considered secondary to the others.

Cover type maps of the Swan Lake and Cutler Reservoir areas have been included as Figures 7 through 9. Nest location overlays accompany them.

\section{NESTING DENSITY}

Nest locations have been shown in Figure 6a, 7a, and $8 a$ for the three areas. In this way the cover vegetation for any nest can be easily and relatively accurately determined. Table 1 lists by species and number of nests the waterfowl which were found nesting on the various areas. From this summary it has been determined that the Swan Lake density was one nest per 0.575 acres. Cutler Area No. 2 had a density of one nest per 5.1 acres. The combined Cutler Reservoir data gave a nesting density of one nest for each 3.39 acres.

Thus, in this first comparison Swan Lake had a density nearly 6 times as great as that found on the areas of Cutler reservoir. Nearly all of the available habitat of Cutler Reservoir was subjected to flooding during the nesting season.

The recurrent flooding creates some lasting indications of different water levels. Evidence of a high water line on emergent vegetation was present before the nesting season started (Figure 6).

Figure 6 High water line on emergerit vegetation of

Cutler Reservoir. Such signs are present before nesting starts.

Gross ecological effects were created by the fluctuating water levels. High water lines, lack of submergent plant species, silt-covered shallows and broad mud flats present conditions which are generally below par for waterfowl nesting habitat. It seems reasonable to believe that these conditions were at least partly responsible for the lower nesting density found on Cutler Reservoir.

NESTING PRODUCTION

General

Tables 2, 3, and 4 are summaries of nest histories of Swan Lake, Cutler reservoir, and Newton reservoir. As used therein, the terms Nest Success and Hatching Success are defined as follows: 

TABIE I. A COMPARISON OF NESTING POPULATIONS

OF THE CACHE VALTEY STUDY AREAS, 1951

Species

Cutler Reservoir Newton Reservoir

Swan Lake

\begin{tabular}{|c|c|c|c|c|c|c|}
\hline & $\begin{array}{c}\text { No. } \\
\text { nests } \\
\end{array}$ & Percent & $\begin{array}{l}\text { No. } \\
\text { nests }\end{array}$ & Percent & $\begin{array}{l}\text { No. } \\
\text { nests }\end{array}$ & Percent \\
\hline Canada Goose & 3 & 5.1 & 0 & 0 & 1 & 0.8 \\
\hline $\begin{array}{l}\text { Common Mallard } \\
\text { American Pintail }\end{array}$ & $\begin{array}{r}28 \\
2\end{array}$ & $\begin{array}{r}47.5 \\
3.4\end{array}$ & $\begin{array}{l}* 5 \text { est. } \\
* 3 \text { est. }\end{array}$ & $\begin{array}{l}23.8 \\
14.3\end{array}$ & $\begin{array}{r}22 \\
2\end{array}$ & $\begin{array}{r}18.5 \\
1.7\end{array}$ \\
\hline $\begin{array}{l}\text { Cinnamon Teal } \\
\text { Shoveller }\end{array}$ & $\begin{array}{l}3 \\
1\end{array}$ & $\begin{array}{l}5.1 \\
1.7\end{array}$ & *2 est. & 9.5 & 1 & 0.8 \\
\hline $\begin{array}{l}\text { Redhead } \\
\text { Canvas-back } \\
\text { Lesser Scaup Duck }\end{array}$ & 11 & 18.6 & & & $\begin{array}{l}1 \\
4 \\
1\end{array}$ & $\begin{array}{l}0.8 \\
3.4 \\
0.8\end{array}$ \\
\hline Ruddy Duck & & & & & 3 & 2.5 \\
\hline Coot & 10 & 16.9 & 10 & 47.6 & 63 & 53.0 \\
\hline $\begin{array}{l}\text { Westem Grebe } \\
\text { Pied-billed Grebe }\end{array}$ & 1 & 1.7 & 1 & 4.8 & $\begin{array}{r}7 \\
14\end{array}$ & $\begin{array}{r}5.9 \\
11.8\end{array}$ \\
\hline TOTAIS & 59 & 100.0 & 21 & 100.0 & 119 & 100.0 \\
\hline
\end{tabular}

* No nests found. Nests inferred from subsequent brood counts. 



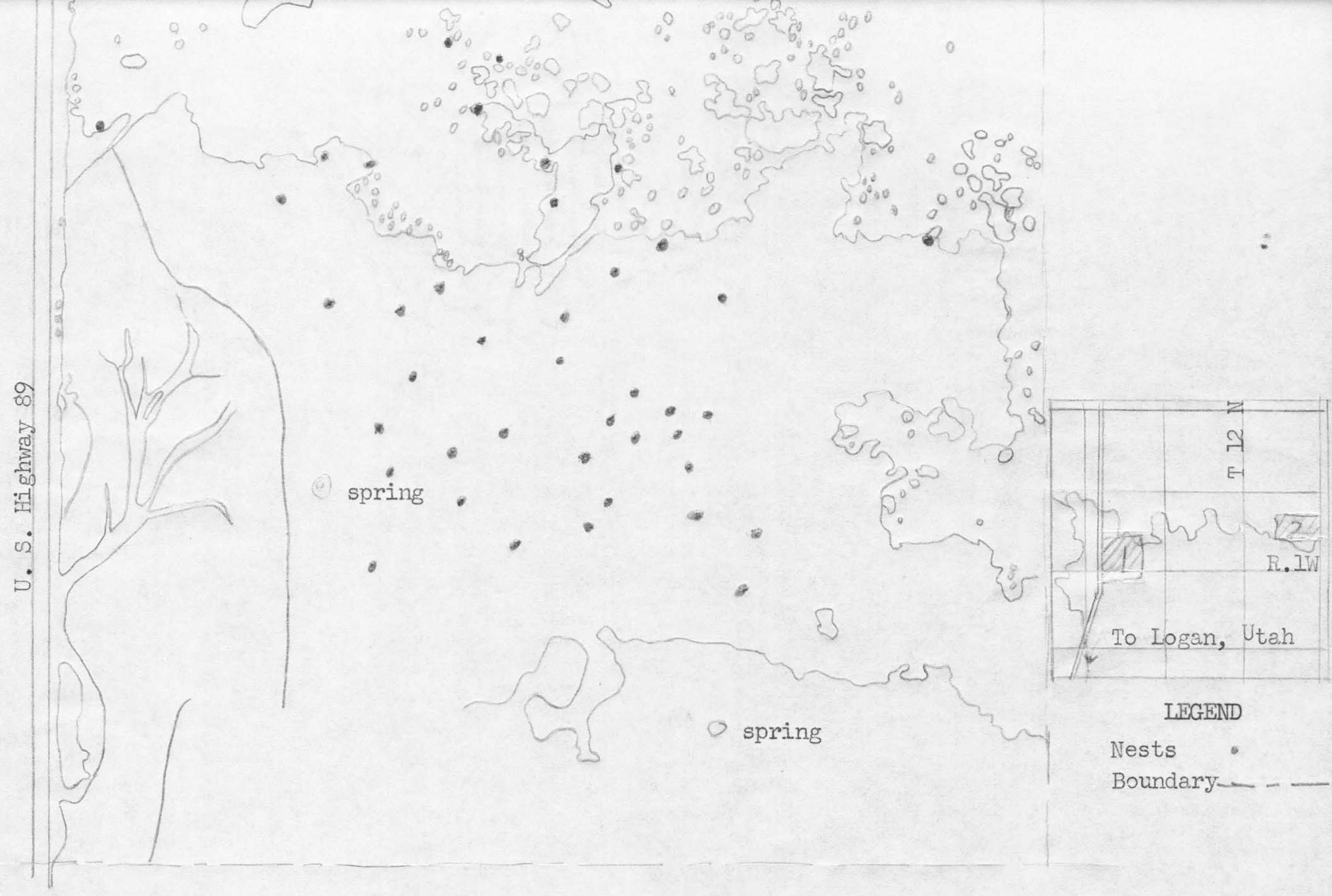

Scale $I^{\prime \prime}=400$ Feet

CUTLER RESERVOIR - AREA 1 - NEST DISTRT BUTION

Figure 9a. Cutler Reservoir Area 1 Nest Distribution 


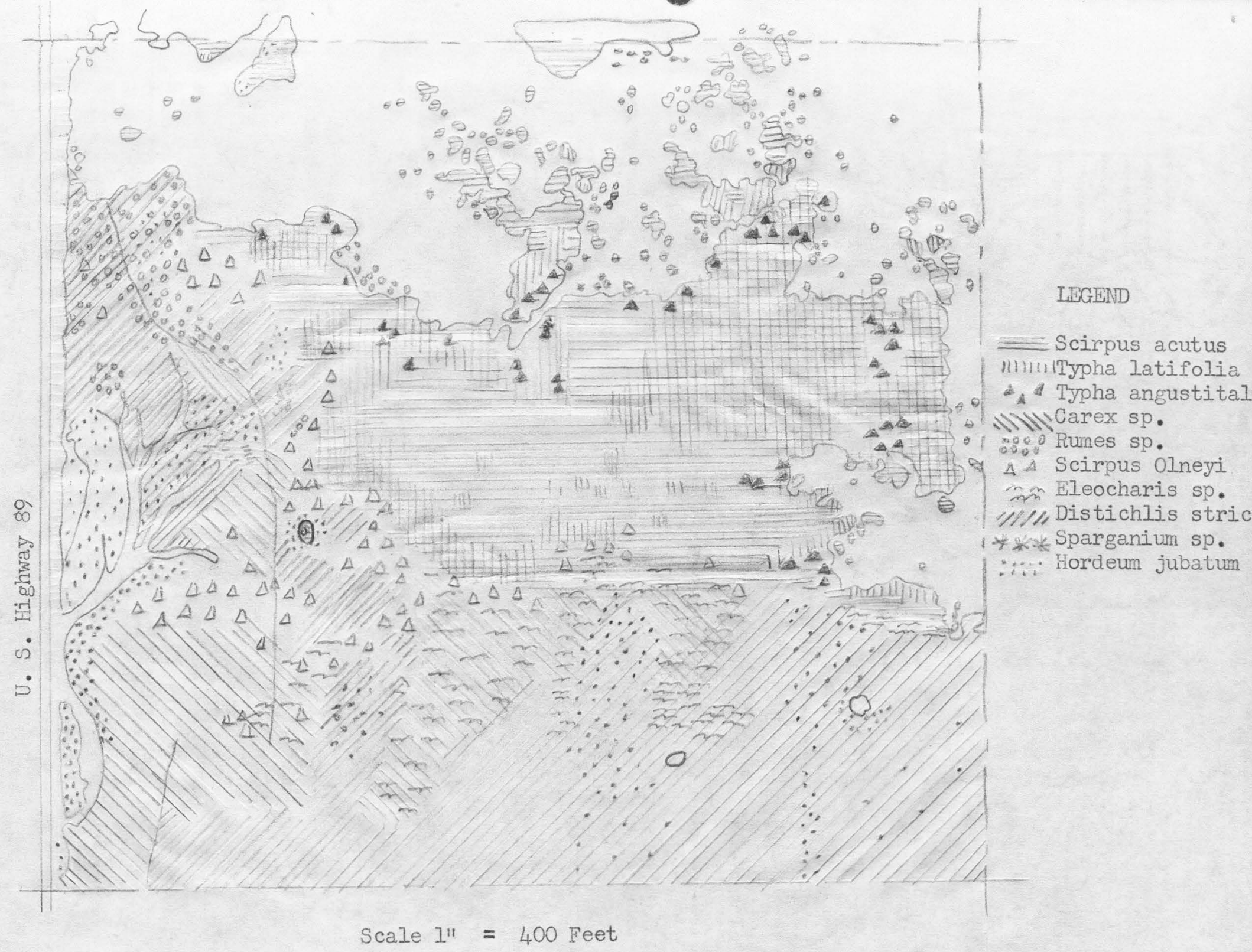

CUTLER RESERVOIR - AREA 1 - COVHR TYPES 


$$
\begin{aligned}
& \text { Nest Success }=100 \%-\frac{\text { Nests with egg failure }}{\text { All nests }} \\
& \text { Hatching Success }=100 \%-\frac{\text { Number of eggs that were not hatched }}{\text { Total number of eggs }}
\end{aligned}
$$

With the exceptions of the Canada goose and redhead, hatching success for species found at Swan Iake was equal to or greater than that of the same species found at Cutler Reservoir and Newton Reservoir. The fact that only one Canada goose and redhead nest was found indicates a high probability that they do not represent hatching successes for these species.

\section{Mortality Factors}

\section{Predation}

Predation on duck nests was low at Swan Lake. Only one instance was observed, and this was attributed to an unidentified mammal which had killed the hen.

There was no predation observed at Newton Reservoir.

All of the predation found on Cutler Reservoir occurred on Area No. 2, and most of this was attributed to magpies which nested in small trees along the abandoned railroad embankment which formed the northern boundary of the area. Five out of the $1_{4}$ nests (about 37 per cent) found on this area were preyed upon. An undetermined mamnal destroyed 4 eggs of a redhead nest. Magpies completely destroyed 2 mallard clutches. Evidence indicated that a bird of undetermined species was responsible for the disappearance of an entire clutch of coot eggs (Figure 27), and the loss of one pintail egg was similarly attributed to an unknown avian predator. Evidence was not conclusive, but magpies were suspected.

Figures 10 to 13 tell much of the history of one mallard nest. Figure 10 shows the exposed nest which was situated alongside a railroad tie. Figure 11 shows the degree of concealment even though there is scarcely any overhead cover. Figure 12 shows three eggs that remain. One of the three had been opened by magpies. Figure 13 shows the evidence of final and complete destruction of the clutch. This bird renested on the dike and successfully terminated a snaller clutch of eggs. No reason for the magpie's disappearance was found. The young had not developed to the stage of leaving the nest much less the ability to fly. They were probably killed by fishermen who occasionally visit the area.

No evidence was found of a relationship between fluctuating water levels and degree of predation although some indirect results of high water created conditions which could favor predation. Rising water reduced the amount of suitable nesting habitat and may have forced sane ducks to nest in thin or exposed cover. 
TABLE 2. SUMMARY OF SWAN LAKE NEST HISTORIES, 1951

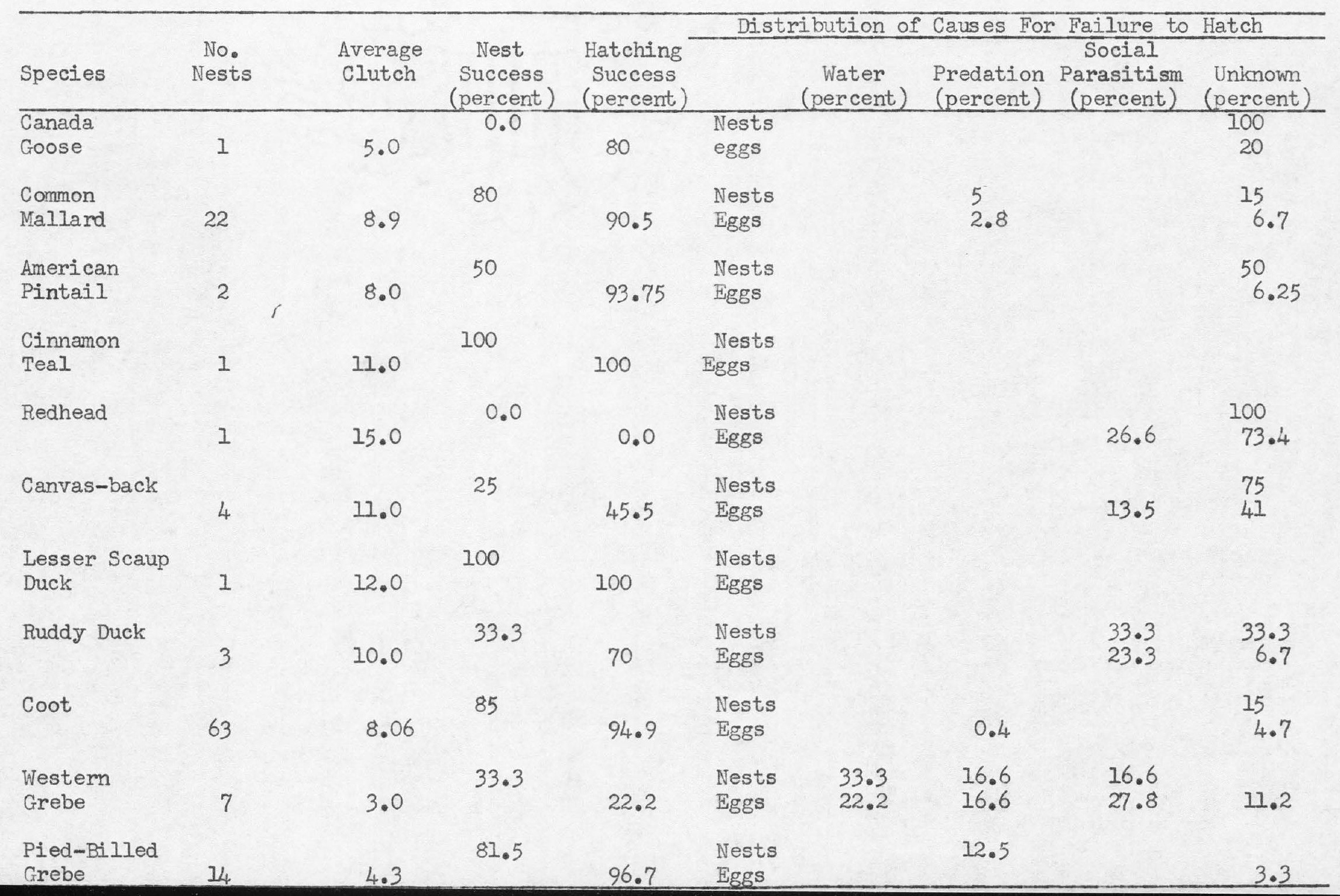


TABLE 3. SUMMARY OF CUTLER RESERVOIR NEST HISTORIES, 1951

\begin{tabular}{|c|c|c|c|c|c|c|c|c|c|}
\hline \multirow[b]{2}{*}{ Species } & \multirow[b]{2}{*}{$\begin{array}{l}\text { No. } \\
\text { Nests }\end{array}$} & \multirow[b]{2}{*}{$\begin{array}{l}\text { Average } \\
\text { Clutch }\end{array}$} & \multirow[b]{2}{*}{$\begin{array}{c}\text { Nest } \\
\text { Success } \\
\text { (percent) }\end{array}$} & \multirow[b]{2}{*}{$\begin{array}{l}\text { Hat c hing } \\
\text { Success } \\
\text { (percent) }\end{array}$} & \multicolumn{5}{|c|}{ Distribution of Causes For Fai lure to Hatch } \\
\hline & & & & & & $\begin{array}{c}\text { Water } \\
\text { (percent) }\end{array}$ & $\begin{array}{l}\text { Predation } \\
\text { (percent) }\end{array}$ & $\begin{array}{c}\text { Social } \\
\text { Parasitism } \\
\text { (percent) }\end{array}$ & $\begin{array}{c}\text { Unknown } \\
\text { (percent) } \\
\end{array}$ \\
\hline $\begin{array}{l}\text { Canada } \\
\text { Goose }\end{array}$ & 3 & $4 \cdot 5$ & 100 & 100 & $\begin{array}{l}\text { Nests } \\
\text { Eggs }\end{array}$ & & & & \\
\hline $\begin{array}{l}\text { Common } \\
\text { Mallard }\end{array}$ & 28 & 8.2 & 25.5 & 45.5 & $\begin{array}{l}\text { Nests } \\
\text { Eggs }\end{array}$ & $\begin{array}{l}50 \\
39.2\end{array}$ & $\begin{array}{l}7.1 \\
7\end{array}$ & 1.7 & $\begin{array}{r}17.9 \\
6.6\end{array}$ \\
\hline $\begin{array}{l}\text { American } \\
\text { Pintail }\end{array}$ & 2 & 8.5 & 50 & 82.3 & $\begin{array}{l}\text { Nests } \\
\text { Eggs }\end{array}$ & & 5.9 & & $\begin{array}{l}50 \\
11.8\end{array}$ \\
\hline $\begin{array}{l}\text { Cinnamon } \\
\text { Teal }\end{array}$ & 3 & 9.7 & 33.3 & 89.7 & $\begin{array}{l}\text { Nests } \\
\text { Eggs }\end{array}$ & & & & $\begin{array}{l}66.6 \\
10.3\end{array}$ \\
\hline Shoveller & 1 & 6 & 0.0 & 0.0 & $\begin{array}{l}\text { Nests } \\
\text { Eggs }\end{array}$ & Accider & ntally dest & oyed by obs & rver \\
\hline Redhead & 11 & 12 & 0.0 & 40.2 & $\begin{array}{l}\text { Nests } \\
\text { Eggs }\end{array}$ & $\begin{array}{l}90 \\
46.0\end{array}$ & $\begin{array}{l}10 \\
3.3\end{array}$ & 3.3 & 8.2 \\
\hline Coot & 10 & 10 & 25 & 72.2 & $\begin{array}{l}\text { Nests } \\
\text { Eggs }\end{array}$ & $\begin{array}{l}25 \\
12.5\end{array}$ & 8.8 & 12.5 & $\begin{array}{r}37.5 \\
6.2\end{array}$ \\
\hline
\end{tabular}


TABLE 4. SUMMARY OF NEWTON RESHRVOIR NEST HISTORIES, 1951

\begin{tabular}{|c|c|c|c|c|c|c|c|c|c|}
\hline \multirow[b]{2}{*}{ Species } & \multirow[b]{2}{*}{$\begin{array}{l}\text { No. } \\
\text { Nests }\end{array}$} & \multirow[b]{2}{*}{$\begin{array}{l}\text { Average } \\
\text { Clutch }\end{array}$} & \multirow[b]{2}{*}{$\begin{array}{c}\text { Nest } \\
\text { Success } \\
\text { (percent) }\end{array}$} & \multirow[b]{2}{*}{$\begin{array}{l}\text { Hatching } \\
\text { Success } \\
\text { (percent) }\end{array}$} & \multicolumn{5}{|c|}{ Distribution of Causes For Fai lure To Hatch } \\
\hline & & & & & & $\begin{array}{c}\text { Water } \\
\text { (percent) }\end{array}$ & $\begin{array}{l}\text { Predation } \\
\text { (percent) }\end{array}$ & $\begin{array}{c}\text { Social } \\
\text { Parasitism } \\
\text { (percent) }\end{array}$ & $\begin{array}{l}\text { Unknown } \\
\text { (percent) }\end{array}$ \\
\hline Coot & 8 & 7.66 & 75 & 73.9 & $\begin{array}{l}\text { Nests } \\
\text { Eggs }\end{array}$ & $\begin{array}{l}25 \\
26.1\end{array}$ & & & \\
\hline $\begin{array}{l}\text { Pied-billed } \\
\text { Grebe }\end{array}$ & 1 & Unknown & 100 & $100 *$ & $\begin{array}{l}\text { Nests } \\
\text { Eggs }\end{array}$ & & & & \\
\hline
\end{tabular}


There was no predation on the Cutler Area, No. 1 in spite of the fact that some nests were left entirely exposed as a result of utilization of surrounding vegetation for nest materials, and the fact that hundreds of California gulls (Iarus californicus, Lawrence) frequented the area.

Social parasitism

Inter-specific social parasitism occurred on both Swan Lake and Cutler reservoir, and evidence indicated the possibility of intra-specific social parasitism. The percentages of parasitic eggs for the various species have been shown in Tables 2 and 3. About 9 per cent of the mallard nests on the Cutler areas were known to be parasitized, but no parasitism of this species was found on Swan Lake. Forty per cent of the redhead nests on the Cutler areas were parasitized as was the single nest of this species found on Swan Lake. On Swan Lake 75 per cent of the canvas-back nests and 66 per cent of the ruddy duck nests were parasitized.

The effects of flooding with the subsequent killing of the embryos at different times produced dead embryos at various stages of development. On the other hand, nests of the mallard were found which had not been subjected to flooding but having dead embryos of different ages. Accidents and other unknown causes can create this result, but it was probably that intra-specific social parasitism was involved at least part of the time.

Unlmown Causes

Eighteen per cent of the nests found on Swan Lake had eggs which failed to hatch for reasons which could not be determined. This amounted to about 10 per cent of all eggs. On the Cutler areas, 35 per cent of the nests or 7 per cent of all eggs were so affected. Tables 2 and 3 give a breakdown by species. The validity of the quantitative findings on flood damage for the Cutler areas is reinforced by the fact that unknown causes of death of eggs are nearly the same as for Swan Lake.

Infertility probably accounted for many of the eggs that failed to hatch, but to determine this under field conditions was difficult and often impossible. Eggs that failed to hatch were opened for examination. In many eggs from Swan Lake and Cutler reservoir, there was no macroscopic evidence of germinal disk or other development. Other eggs were found with dead embryos at various stages of development, and it was impossible to determine the cause of death. Some of these eggs were found in nests which had not been subjected to water damage.

Water as a Mortality Factor

Damage to waterfowl nests by water was both direct and indirect. Direct factors were (I) flooding of the duck nests and partial or complete submergence of the eggs and (2) possibly drying of nests of the grebes by a lowered water level. Indirect factors were (1) spilling or burying of the eggs by the hens in their efforts to cope with changes in water levels, (2) toppling of nests made instable by dropping water levels, and (3) isolation of the nest as in the case of grebes and possibly coots. 
Dropping water levels left the coot and grebe nests in such a position that the birds could not reach them (Figure 14 and 15).

\begin{abstract}
Figure $\mathbf{1 4}_{4}$ Western grebe nest at Swan Lake. The cause of desertion of this nest is attributed to a drop in water level which left this nest beyond the reach of the aquatic bird. The subsequent drying of vegetation may also have been of some influence.
\end{abstract}

\section{Coot Nesting as Affected by Water Level Fluctuations}

Coots were the most numerous species of waterfowl to nest at Newton Reservoir. Typically, their nests were found in the willows that border the reservoir, and most of them were at least partially dependent upon these willows for support. Some were built in crotches at water level, others were built on branches that projected over the water. When the water level dropped, the nests lacked support and tilted, spilling their contents into the water. Nests which had been built in crotches avoided this fate, but instead many of them were left too high to be accessible to the parent birds. When the level dropped, nests which were a few inches above water, were left more than 50 inches above dry ground and as far as 50 yards over bare soil to the nearest water. One clutch was incubated and the eggs hatched even though the water level had dropped to 36 inches below the nest. Another was attended when 50 inches above water, but it was deserted after the water's edge receded.

These high nests had a heavy mortality among the newly hatched birds. The drop from the nest may not have been the only factor involved. Young coots were observed to drop as much as 4 feet without injury, but dead young were found around several of the high nests on which there was a fairly complete history.

Without a doubt, the falling water level stimulated the building of additional nests by birds whose nests were left at undesirable heights above the water, but they were frustrated attempts. As many as 3 or 4 new coots nests at different levels were found within a foot of each other. This close grouping and the territorialism of the species precludes the possibility of more than one pair of birds having been involved.

Coots proved to be attentive parents when the water rose, and in all instances they attempted to protect their clutches from rising water levels.

Figure 15. Coot nest at Newton Reservoir. At the time this picture was taken, the nest stood at 50.5 inches above ground. Evidence of former water level is indicated by the profuse rooting of the willow branches in which the nest was found. 
Coot clutches suffered greatest damage by water when the level dropped. The nests generally were built up with the rising water, and as many as three or four old egg levels were present in some instances. When the water dropped, the nests usually lacked structural stability. No direct observations were made, but it was thought that the parents upset the nests and spilled the eggs as they climbed onto the nest and left it.

Figure 16 Typical coot nest on Cutler Reservoir. Much new material has been added to this nest, and in spite of the high water, the eggs remained dry. Anchored to vegetation and rather bulky this nest did not tip when the water level dropped.

One unusual incident of nesting behavior of a coot was noted and photographed during the study (Figure 17).

Figure 17 A double coot nest in which the hen had built a lower nest and spilled or moved the eggs into it when the water level dropped.

When this nest was found, the water level was high, and nothing out of the ordinary was noted. On the next visit, the water level had fallen, and a second and lower nest had been built. The surprising fact was that all of the eggs were in the lower nest. When again the nest was visited, all of the eggs had disappeared and the reason was not determined.

Grebe Nesting as Affected by Water Level Fluctuations

Western grebe nests were the only nests subjected to damage by water on Swan Lake. This damage was brought about as an indirect effect when the nests were stranded by a 1.25 foot drop in the water level (Figure 14). It is probable that the parent was unable to reach the nest. The birds are not noted for incubating diligence, and the possibility does exist that the dampness of the vegetation upon which the eggs are placed is essential to hatching. When the vegetation dries, incubation may be interrupted or even stoped.

Duck Nesting as Affected by Water Level Fluctuations

Flooding, as a result of water level fluctuation was the greatest mortality factor affecting hatching success on the Cutler reservoir. About 31 per cent of the total waterfowl production was lost because of flooding. Coots, mallards and redheads were the only species affected, and nearly 94 per cent of the danage was confined to mallards and redheads. Fifty per cent of the mallard nests on Cutler reservoir were partially or completely destroyed by water. This was a loss of over 39 per cent of all mallard eggs (Table 3). Ninety per cent of the redhead nests were subjected to flooding, but in contrast with the mallards just 46 per cent of the eggs were killed. 
The above results of data analysis were particularly interesting because they substantiated a similar conclusion made in the field. Even though 90 per cent of the redhead nests were subjected to flooding, at least part of each clutch was successfully hatched. In contrast, about 57 per cent of the flooded mallard nests were a complete loss and abandoned by the hen.

Mortality due to flooding occurred during all stages of incubation, and even during actual hatching some clutches were destroyed (Figure 18).

\author{
Figure 18. This mallard clutch from the Cutler Reser- \\ was complete. \\ voir was flooded during hatching. The loss
}

Redhead ducks were more successful in adding to their nests during rising water levels than were mallards, but eggs were frequently buried or spilled in the process. As a result of the utilization of nearby vegetation for nest material, the redhead nests frequently were left entirely exposed (Figure 19).

Figure 19. Redhead nest on Cutler Area No. I showing the lack of overhead cover that resulted when the hen utilized the surrounding vegetation for nest material. In spite of such "advertising", no predation occurred to these nests.

The lack of down and the fresh appearance of the nest materials were the most easily recognized signs of additions. Nests were frequently found in this condition, and the final check usually revealed one or more earlier egg levels as indicated by a heavy down layer at a low level and one or more lighter ones above this.

Because mallards generally choose a slightly higher nesting site than redheads, their nests were less likely to be damaged by a rising water level. In spite of this advantage, mallard nests which were affected by high water were complete losses about 57 per cent of the time (Figures 20, 21, 22).

Figure 20. Mallard nest flooded during laying. Some effort had been made to save this nest. Some utilization may be seen. Three other eggs had been spilled from the nest.

Figure 21. Flooded mallard nest for which the hen made no effort to elevate the clutch. Concealing vegetation is still untouched. 
Figure 22. Flooded mallard nest on the Cutler Reservoir. This is an example of the lack of effort to elevate the nest. None of the surrounding vegetation has been cropped. (The overhead vegetation has been pushed out of the way in order to admit light for photographing.)

In some instances, mallards successfully raised their eggs and saved the entire clutch (Figure 23).

Figure 23. Mallard nest on the Cutler Reservoir that had been successfully raised by the hen. The cropped condition of the surrounding vegetation is readily seen.

Buoyancy of Nest Materials

The materials from which the nests were built varied greatly. Some were built entirely of bulrush (Scirpus acutus, Muhl.); others consisted of cattail (Typha sp.). Many nests were built of both and the proportions varied between nests. Because there did appear to be some difference in the buoyancy of nests, tests were conducted in order to determine whether or not some materials were more buoyant than others.

Four inch lengths of Scirpus acutus stems and leaves of cattail (Tyoha latifolia, Linnaeus) were used in the experiment. Care was exercised to include a wide range of thicknesses of each. The different specimens were allowed to float freely on an open surface of water. Bulrush generally absorbed water more quickly. The first bulrush sank during the eleventh day, but no cattail sank until the thirteenth day. In both instances the specimens with smallest cross sectional area sank the most quickly. The thickest sections of bulrush were floating when the last cattail sank.

Cross sectional areas were not computed for this experiment, but an attempt was made to estimate these values and use samples of cattail and bulrush with comparable areas, particularly at the extremes. Bulrush appeared better able than cattail to withstand water logging, but the difference was slight. It was concluded that for the purposes of this study, there was no significant difference in floatability of bulrush and cattail.

Degree of Tolerance by Waterfowl to Water Level Fluctuations

The most important results of this study are probably those concerning specific features of the flooding which caused damage to waterfowl nests. Pertinent facts regarding the Cutler reservoir water levels are involved and should be kept in mind. The hydro-electric power plant at Cutler dam is used to supply whatever additional power is required to meet the demand of a large commercial electric system served by several other power producing plants. This operation is termed "load control". As a result of such fluctuating denand the Cutler power plant may range from maximum to minimum output several times a day. 
The dam site is narrow and shallow; therefore, the heavy demands for water create a "draw-down" that is known to affect the area of the Cache Junction gage. This "draw-down" creates water surface gradients that have been as great as one half-foot per mile.

The areas used in this study were usually visited on successive days and generally, a minimum of at least several days elapsed between the visits to any particular nest. Water depth was measured at each nest site, but changes that occurred between visits could not be known if beginning and final levels were similar. A more complete picture of changes was made possible on the Cutler Reservoir where recording gage data was used, but even this was at times inadequate. Water depths at nest sites were later correlated with gage readings for the same day. Changes in water depth at nest sites between successive visits were computed and compared with differences of gage readings for the same days. The results of all nest comparisons where both data were available indicated that the total of all changes as indicated by gage readings average 18 per cent higher than similar data taken at the nest. Some of this discrepancy may have been due to errors in measurement at the nest, particularly when nests were over a soft muck and/or silt bottom. In instances like this the location of the "bottom" was an arbitrary choice each time a measurement was taken.

A stake gage was installed on each of the Cutler areas in order to determine the degree of accuracy with which the Cache Junction gage represented the surface conditions of the sample areas. Three periods were checked on Cutler Area No. 1. The total change as measured on a stake was 24 per cent below that indicated by the recording gage. A similar check was made on the Cutler Area No. 2, and a check of four periods showed that the total change indicated by the stake gage was 0.4 per cent higher than recorded by the automatic gage at Cache Junction, Utah.

The foregoing data on water level readings established the possibility that the following discussion can have an error as great as 24 per cent or as little as 0.4 per cent.

Mallard nests were subjected to maximum rises in water level of from 1.08 feet to 2.58 feet. Hatching success was affected at both ends of this range, but some mallard clutches escaped loss when subjected to rises of from 0.83 feet to 1.92 feet. It is concluded that within the latter range, total rise is not as important as the amount of rise per unit of time. Based on gage data, it was found that a rate of rise of 0.166 feet per day for 5 days killed eggs in 9 nests or in 53 per cent of those affected. Six clutches were not affected, and in 2 nests the effect could not be determined. One nest was subjected to a rise of 0.293 feet per day for 3 days, and only 2 of the 10 eggs hatched, 7 eggs were killed during incubation by the water, and one failed to hatch for reasons which could not be explained.

Redhead duck nests were subjected to maximum rises of from 1.03 feet to 2.11 feet. Both extremes produced lethal effects. A maximum rate of rise of 0.166 feet per day for 5 days killed an average of 40 per cent of the eggs in every nest affected, but a rise of .293 feet for 3 days ppoduced loss of 77 per cent of the eggs in the one nest which was so affected. 
Figure 24 shows a typical redhead nest which had been raised by the hen when the water rose. The cropped surroundings are typical of the reduction in cover where vegetation has been added to a nest. In spite of the care shown, two eggs of this clutch were killed by the water. The reason for this probably lies in the fact that all eggs are generally not on the same level. Eggs in the center of a clutch are usually lower than those on the perimeter. This is particularly true recently after they have been disturbed by the hen when she raised them.

Figure 24. A redhead nest on Cutler Reservoir which has been raised to cope with a rising water level. The typical cropped condition around the nest is evident.

BROOD SURVIVAL

\section{GENERAI}

The number of waterfowl that reach maturity is dependent upon the number that hatch; with this exception, brood survival is independent of hatching success. However, factors which affect hatching success may also affect survival. Predation, climatic conditions and other biotic and environmental factors are ever present in the lives of waterfowl.

This study was designed and intended to determine the effects of water level changes on waterfowl production. From the first phase of this problem it was determined that hatching success was adversely affected. The second phase was intended to determine possible relationships of water level changes to brood survival.

Most of the data for the brood survival study was gathered during June, July and August, but a record was made whenever a brood was seen. Broods of geese were first observed in mid-May, and the first broods of ducks were noted during the latter part of the month. Data was recorded only when there was reasonable assurance that the entire brood had been seen; this reduced the number of usable observations but made possible greater accuracy. Broods were designated as follows: Class I, all downy ducklings; Class II, small ducklings with definite pinfeathers to and including larger ducklings twothirds grown and with a partial wing featherring; Class III, juveniles with wings about half feathered to and including those capable of short flights. According to species and class, the averages for bi rds from all study areas has been compared (Table 5). In order to make additional comparisons, the data for all ducks as a group have been tabulated for the three study areas (Table 6).

\section{SWAN IAKE BROOD DATA}

A total of 148 duck and coot broods were observed; about 65 per cent of these were from the Swan Lake control area. 
Average numbers of birds per brood decrease as they approach maturity, but some discrepencies were noted in the data. Canvasback Class III broods average 6 birds whereas the average Class II brood had but 4 birds. Similar results are seen for the mallard, green-winged-teal and cinnamon teal (table 5). In every instance, however, the number of observed broods was 4 or less, and it is thought that the small sample size is at least partly responsible. Another factor which may effect an apparent increase in brood size is the fact that two or more broods frequent]-y combine into one group.

When the data on all duck broods were combined, the results showed the expected decline in average number per brood as the birds grew older (Table 6). It is thought that this serves as a favorable basis for comparison with broods of other parts of Cache Valley for the same period.

Coots on all areas displayed a high degree of gregariousness. This made brood censusing difficult and often impossible because the members of the individual broods often could not be distinguished.

The dense submergent vegetation of Swan Lake proved very attractive to ducks particularly after they had reached Class II age. Class I brocds favored the cover of emergent vegetation along the perimeter of the open water. A mall boat and two kinds of canoes were used at different times in making brood counts. A small canoe of wood and canvas construction was found best adapted to brood count and other waterfowl observations were made from this concealed position. This method seemed most satisfactory for separating definite broods from chance groupings of birds on the lake.

NEWTON RHSERVOIR BROOD DATA

The small size of Newton Reservoir made it possible to count the broods which were present with assurance of reasonable accuracy. A total of 9 nests were found during the study, and all of them were coot nests. However, as many as 8 separate broods of ducks were counted in one census. Many of these broods were thought to have moved into the reservoir from nest sites along the source stream and from nearby fields. Farmers reported the destruction of 2 nests while plowing the adjacent stubble fields.

The highest survival of Class II and Class III broods occurred at Newton reservoir, but the fact that both of these averages were based on relatively small samples should be considered in a comparison of the Class II broods (Table 6). Several factors may have favored the slightly higher survival found on the Newton reservoir.

The fringe of willows along most of the edge furnished excellent protective cover. Submergent vegetation was brought nearer the surface as the water receded so that a realtively new source of insects and food was ever present during growth. A third factor which possibly helped brood survival on Newton reservoir was the reappearance of small islands as the water level dropped. These islands furnished secure resting places for the birds.

It is doubtful, however, that the greater average brood survival on Newton reservoir is significant. 
TABLE 5. A COMPARISON OF BROOD SURVIVAL BY AGE CLASS

CACHE VALLEY, UTAH AND IDAHO

1951

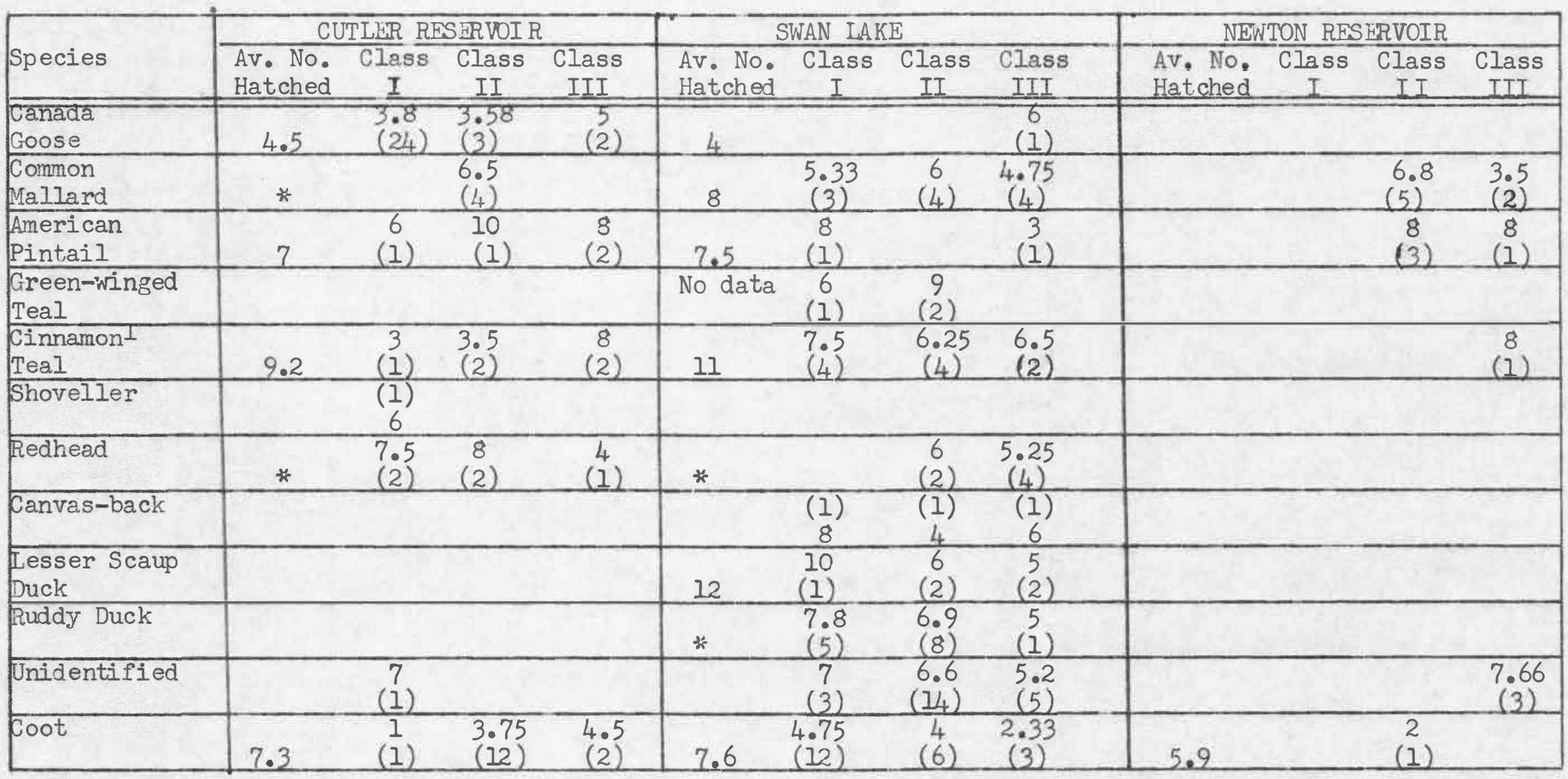

N Average hatched $=$ average clutch $\mathrm{x}$ hatching success

* Less than average of Class I broods

() Numbers in parentheses indicate broods counted

I Includes Blue-winged Teal 
Table 6. A COMPARISON OF AVERAGE SIZES OF WATERFOWL BROODS FROM SWAN LAKE, NEWTON AND CUTLER RESERVOIRS

\section{1}

$\begin{array}{ccc}\text { Class I } & \text { Class II } & \text { Class III } \\ \text { Av. No. } & \text { Av. No. } & \text { Av. No. }\end{array}$

Size Broods Size Broods Size Broods

Swan Lake Ducks

Coots

$\begin{array}{ll}7.3 & (19) \\ 4.75 & (12)\end{array}$

$\begin{array}{ll}6.6 & (37) \\ 4.0 & (6)\end{array}$

$5.2(20)$

Newton Reservoir

Ducks
Coots

$\begin{array}{ll}7.4 & (11) \\ (1)\end{array}$

$2.33(3)$

Cutler Reservoir Ducks

Coots

$6.2(5)$

$6.5(10)$

7.2

3.75 (12)

$5.75(4)$

1.0 (1)

4.5

(5)

Average size of brood $=\frac{\text { Total birds per class }}{\text { Total broods per class }}$ 


\section{CUTLER RESERVOIR BROOD DATA}

About 5 miles of the upper end of Cutler reservoir was censused during the brood study. This included the nesting study areas and all of the land between them. To begin with, the nesting population was sma.1] in proportion to the area involved. Several other factors arose which made brood censusing difficult and interfered with obtaining a larger sample.

A brief but severe outbreak of botulism occurred during the time of the brood study on Cutler reservoir. Dead ducks were found from Area No. 1 down to Area No. 2, but the epizootic was difinitely concentrated in the upper, vegetated shallows near which, unfortunately, the greatest nesting density had occurred (Figure 25). A sample of 52 dead birds was collected and classified; about 60 per cent were juveniles of all age classes. It was estimated that several hundred ducks and coots died of botulism on Cutler reservoir, but because transient pintails were in the area, an estimate of the loss of resident birds was uncertain. Based on the fraction of juveniles present in the sample, it was thought that at least 20 per cent of the resident population died.

Often, groups of birds which appeared to be entire broods were found dead within a very small area. The epizootic occurred during a period of low levels, but when the water again rose, the incidence of infection dropped to zero.

Figure 25. Ducks sick with botulism often tried to

leave the water. Many such small islets

of Cutler Area No. I were dotted with sick and dead birds.

During the brood study, it became necessary to use an aluminum canoe instead of the one of wood and fabric. Certain features of the aluminum craft impaired the efficiency of the searching. The metal hull amplified any noise whi ch was created and alarmed the birds for a far greater radius than did the comparatively noiseless wooden canoe. For all its many other fine features the aluminum canoe was not desirable for brood censusing in this study.

The data from Cutler reservoir indicate that the Class III broods averaged 2 more birds each than did the Swan Lake broods, but the Class II are reasonably similar for both areas (Table 6). It seems unlikely that 7.2 birds per Class III brood represents the true average. Only 5 Class III broods were observed on the Cutler reservoir and this fact suggests one reason for the high average number. Another reason could be that combinations of broods were observed and recorded.

More Class II broods were observed on all areas than any other age group, and in numbers this group represented the most favorable basis for a comparison of survivals. 
Since the average number of birds per brood on the Cutler reservoir was only 0.1 bird below that of the control area, it was concluded that there was no direct relationship between brood survival and fluctuating water levels.

\section{WATERFOWL FOOD PLANT PRODUC TION}

\section{GENERAL}

Young ducklings feed more on aquatic invertebrates than they do on vegetation. These aquatic invertebrates are directly or indirectly dependent upon vegetation for food and cover. A lack of time prevented the study of the animal food available to young ducks when the brood survival study was made. However, seeds and vegetative parts of most plants, particularly waterfowl food plants, do not mature until late sumer, and the collection of these could be more conveniently made at that time. Plants reflect environmental conditions quite readily; therefore, a quantitative and qualitative study of the plant life of the three areas could show important differences between the areas which would have an influence on their respective waterfowl brood survivals.

Many factors affect plant growth, but because all lands of this study were in the same general area, had the same elevation, and were studied in the sane season, these important factors were reasonably similar. If the study revealed important differences between the areas, they might be due to the influence of the different water level characteristics. Martin and Uhler (1939) describe irrigation and hydroelectric reservoirs as "biological deserts" when the fluctuations occur during the growing season.

Low and Bellrose (1944) found that in the Illinois river valley both vegetative growth and seed production were adversely affected by fluctuating water levels.

In general, silting, low transparency, a lack of aeration and dehydration are primary factors involved in areas of fluctuating water level.

Typically much of the upper end of the Cutler reservoir is a heavily silted, shallow water area (Figure 26).

Figure 26. Typical vegetation growing in the zone of flooding on Cutler Area No. 1. Silt-

ing is evident as is suspended debris in the vegetation.

Principal plant species shown here is Scirpus acutus.

\section{SELECTION OF SAMPLES}

Sumergent plants were taken from water depths of from 6 to 24 inches at the time of collection. Because of fluctuating and dropping water 
levels there was little or no reason to use more specific ranges of depth. Under such conditions one site may have 6 inches of water one day and 30 inches several days later.

Seeds from emergent waterfowl food plants were collected after they had ripened, so that the same species were collected from all areas within two weeks time. Submergent species were collected from Newton reservoir and Swan lake within a short period of time, but the occurrence of these species on Cutler reservoir and Swan lake, consequently, mature stands that did not show evidence of grazing were difficult to locate. For this reason a random pattern of sampling was deemed impractical.

Samples were collected from as pure and untouched stands as could be found .

A total of 255 samples including 16 different species of waterfowl food plants were collected for this study (Table 7). About one-third of the species and one-fifth of the number of samples was taken from submergent species.

\section{QUAIITATIVE DIFFERENCE IN FOOD PIANT PRODUC TION}

Forty-one plants common to 2 or more areas were selected for a qualitative comparison ( $\mathrm{Table} \mathrm{8)}$. One of the most striking differences between the areas is the scarcity of submergent species on Cutler reservoir. There was no significant growth of submergent species on Cutler reservoir. With the exception of horned pondweed (Zannichellia palustris I.) the submergents found were occasional plants or small isolated patches. This was considered the most important difference found between the areas, and it is believed that this shortage of an essential vegetation food type would be detrimental to optimum waterfowl production if the waterfowl population was larger. Cutler reservoir also had large areas of foxtail barley (Hordeum jubatum L.), hairy chess (Bromus commutatus Schrad.), and other weed grasses and plants of little or no value as waterfowl foods. Plants of this type were largely absent from Swan lake.

Newton reservoir presented a far less drastic condition in that there were large areas of submergent species. The steep angle of the bottom limited the zone of growth and reduced the effective area of feeding to but a relatively narrow strip. Inshore the vegetation was exposed to dessication; in the opposite direction the depth soon became too great for the young birds.

\section{QUANTITATIVE DI FFERENCES IN FOOD PLANT PRODUC TION}

The differences in weight per unit of area between the areas are complex and somewhat difficult to explain. With the sole exception of Zannichellia palustris, the submergent species on Swan Iake produced a greater weight of air-dry vegetation than either Cutler or Newton reservoirs (Table 7). The average air-dry weight of a square meter of this plant from Cutler reservoir was about 50 grams or 22 per cent less than that produced on Swan Lake. The reason why the weight of this was greater is probably 
Table 7. A COMPARISON OF THE RELATIVE ABUNDANCE OF SELECTED PLANTS FROM SWAN IAKE, NEWTON AND CUTLER RESERVOIRS

1951

Species

Marsilea vestita

Typha latifolia

Typha angustifolia

Aparganium eurycarpum

Potamogetom pectinatus

Ruppia maritima.

Zannichellia palustris

Triglochin maritima

Alisma Plantago-aquatica

Sagittaris cuneata

Bromus commutatus

Distichlis stricta

Phraqmites communis

Hordeum jubatum

Beckmannia syzigachne

Phalaris arundinacea

Echinochloa crusgalli

Scirpus olneyi

Scirpus acutus

Scirpus paludosus

Eleocharis macrostachya

Carex spectabilis

Carex aquatilis

Carex rostrata

Spirodela polyrhiza

Lemna trisulca

Lemna minor

Juncus balticus

Rumex crispus

Rumex maritimus

Polygonum amphibium

Polygonum lapathifolium

Polygonum Persicaria

Salicornia rubra

Suaeda occidentalis

ceratophyllum demersum

Hippuris vulgaris

Myriophyllum exalbescens

Utricularia sp.

Xanthium sp.

Chara sp.
Cutler Reservoin

$2 *$
5
3
3
1

Unknown

2

3

2

2

3

4

2

3

3

2

3

3

5

2

3

2

3

1

Unknown

2

2

3

3

Unknown

1

3

3

3

3

Unknown

1

1

Unknown

3

absent
Swan Lake Newton Reservoir

Unknown Unknown

52

Absent Unknown

3 Absent

$4 \quad 4$

$3 \quad 3$

3 Unknown

2 Unknown

32

32

Unknown Unknown

3 Unknown

Absent Absent

23

2 Unknown

Unknown Unknown

22

3 Unknown

52

Absent 2

34

3 Unknown

32

Unknown Unknown

3 Unknown

$4 . \quad$ Unknown

4 Unknown

33

23

44

1 Unknown

34

Unknown Unknown

Absent 2

Absent Unknown

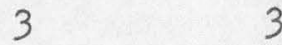

2 Unknown

5 Unknown

2 Unknown

24

43

* The degrees of abundance are:

$$
\text { A bundant, Common, Frequent, Infrequent, Rare }
$$


due to the weight of the foreign matter included. The plants from both Cutler reservoir and Swan lake were contaminated with a film of silt and dirt which could not be completely washed from the plants. Water turbidities of Cutler reservoir were as great as 45 parts per million; whereas, Swan lake had a turbidity of 5 parts per million. This difference in exposure to silt probably accounts for the increased weight of the Cutler reservoir samples.

Fmergent species from Swan lake with its stable water level generally were lower in seed production than cutler reservoir with its fluctuating water levels. The reasons for this difference are obscure. In the case of Triglochin maritima, the density at Swan lake was less than that on Cutler reservoir. Sparganium eurycarpum grew as an emergent species in the fluctuating waters of Cutler reservoir and produced an average of 6.7 grams of seed per square meter. This species was essentially a terrestrial plant on Swan Lake and produced an average of 2.8 grams of seed per square meter. In the IlJinois River Valley, this species produced 288 grams of seed per square meter under stabilized water levels (Low and Bellrose, 1944 ). The difference in seed production of this species in the Illinois River Valley and Cache Valley is significant. The terrestrial niche of this species on the Swan Lake area indicated ecological succession the competition of which could only retard general growth and seed production. This was evident in the general thin and stunted growth. On Cutler reservoir, Sparganium eurycarpum generally grew in dense stands, but seedbearing plants were usually confined to a strip just a few feet wide around the perimeter of the patches. The low weight of seed per unit of area is in part explained by the fact that samples were taken across the diameters of the patches and included many blanks. As near as could be determined, the other species which produced less at Swan lake were otherwise comparable. Only one species, Polygonum Persicaria, produced a greater weight of seed at Swan lake than it did at Cutler reservoir. The plant was a giant variety, and this fact probably accounted for the greater weight.

\section{EFFECT OF FLUCTUATING AND DROPPING WATER LEVELS}

The results of this study indicate that the greatest differences in vegetation between areas of fluctuating, falling and stable water levels occur in submergent species. Both the quantity and quality are greatly reduced in areas of fluctuating water level, but are affected to a lesser degree in an area where the water levels drop during the latter part of the growth period.

The soil supporting emergent species on the area of fluctuating levels was alternately inundated and exposed; whereas, the riparian soils of the area of stable water levels was generally associated with a slowly retreating water level. This fluctuating water effects a forced change of soil air, and this is thought to be a possible reason for the greater seed production under these conditions.

Fluctuating levels inhibit the growth of submergent plants and may have some influence on invertebrate animal life inhabiting those waters. Although brood survivals showed no appreciable difference between the areas, this inhibiting of submergent plant growth could indirectly affect waterfowl production. 
TABLE 8. A COMPARI SON OF WATERFOWL FOOD PRODUCTION IN 1951 FROM SWAN LAKE, NEWTON AND CUTLER RESERVOIRS

\begin{tabular}{|c|c|c|c|c|c|c|}
\hline \multirow[b]{2}{*}{ Species } & \multicolumn{3}{|c|}{ Grams Per Square Meter } & \multicolumn{3}{|c|}{ ML. Per Square Meter } \\
\hline & Cutler & Swan & Newton & Cutler & Swan & \\
\hline $\begin{array}{l}\text { Sparganium eurycarpum } \\
\text { Potamogeton pectinatus } \\
\text { Zannichellia palustris } \\
\text { Triglochin maritima } \\
\text { Ruppia maritima } \\
\text { Echinochloa crusgalli } \\
\text { Scirpus acutus } \\
\text { Eleocharis macrostachya } \\
\text { Carex spectabilis } \\
\text { Carex aquatilis } \\
\text { Rumex crispus } \\
\text { Rumex maritima } \\
\text { Polygonum lapathafolium } \\
\text { Polygonum Persicaria } \\
\text { Ceratophyllum demersum } \\
\text { Myriophyllum exalbescens }\end{array}$ & $\begin{array}{ll}6.714 & (35) * \\
22.61 & (5) \\
224.65 & (6) \\
22.125 & (8) \\
& \\
24.855 & (18) \\
41.5 & (2) \\
17.0 & (1) \\
15.35 & (3) \\
62.863 & (14) \\
& \\
29.334 & (5) \\
203.0 & (1)\end{array}$ & 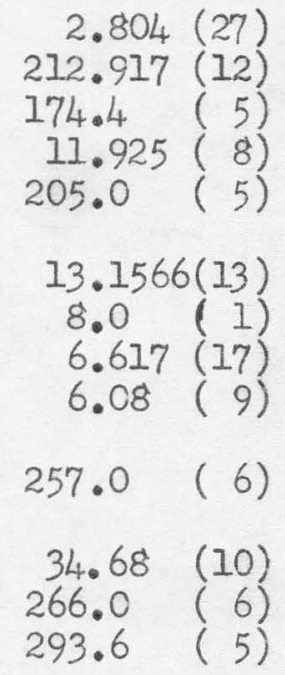 & $\begin{array}{cc}86.0 & \text { (3) } \\
69.0 & \text { (2) } \\
5.362 & (3) \\
& \\
46.38 & (6) \\
190.596 & (5) \\
7.25 & (8) \\
151.66 & (6)\end{array}$ & $\begin{array}{c}35.0 \\
30.0 \\
45.65 \\
146.35\end{array}$ & $\begin{array}{l}6.498 \\
300.0 \\
180.0 \\
33.75 \\
490.0 \\
17.921 \\
10.0 \\
28.235 \\
137.288 \\
591.6 \\
54.5 \\
333.0 \\
640.0\end{array}$ & $\begin{array}{c}104.166 \\
553.8 \\
8.75 \\
158.33\end{array}$ \\
\hline
\end{tabular}

* Numbers in parentheses indicate samples 
Most areas of water impoundment are at least under partial control, and some of these areas are important to nesting waterfowl. Without doubt, the primary function of these impoundments, whether they are devoted to flood control, hydroelectric power production, irrigation or other purpose, is more valuable from a monetary standpoint than the potential value of the waterfowl that could be produced.

When practical the conservation of one resource should not be effected to the detriment of another. Wildlife interests may not be the primary concern on areas of multiple use, but in many instances, wildlife interests can be protected by judicious management based on sound knowledge.

With information of the type which has been gathered in this study, it is possible that in the future some impoundments can be managed so as to present more favorable conditions for nesting waterfowl without appreciably reducing the efficiency of the project.

By keeping the rate of rise below the point of maximum tolerance, maximum water capacity may be stored with less destruction to nesting waterfowl. It is known that the total rise may frequently exceed the limits with which ducks can cope, but on some areas it does not. These suggestions are meant to be applied where practical and where other known factors are consider ed. Local conditions will vary. Tolerances as to total rise and rate of rise differ between the species of waterfowl. From this it is evident that similar studies should be made elsewhere on different species of waterfowl and on experimental areas on which there is control of the water.

Waterfowl production is reduced by fluctuating and falling water levels due to both direct and indirect effects during the nesting period. From this study it was concluded that the direct effects of flooding during fluctuations were a greater mortality factor than the indirect effects of a falling water level.

Coot nests are affected more by a falling water level than they are by a rising water level. Under normal conditions their nests are typically close to the surface and near open water. Because of this they are subjected to greater changes in water level than the nests of other species such as the mallard which are more upland and distant from the water. All of $t$ he coot nests on Cutler reservoir were affected by fluctuating water levels, but only 12 per cent of the eggs were killed. Ninety per cent of the redhead nests were subjected to damage by water with a loss of 46 per cent of the eggs. Only 50 per cent of the mallard nests on Cutler reservoir were affected by water, but 39 per cent of the eggs were lost. From this it is concluded that coots are better able to cope with fluctuating water levels than the two species of ducks mentioned. Total loss to redheads was greater, but the proportion of eggs lost to nests affected was less than for the mallard. This indicates that the redhead is better able to contend with rising water than the mallard

A total rise of 2.58 feet of water caused damage to all of the affected nests, but some nests escaped damage when the water rose 1.92 feet. It is concluded from this that the maximum rise with which ducks can cope is about 2 feet. 


\section{CONCLUSIONS}

Total rise is not the only factor of water levels to be considered; rate of rise is equally important. An excessive rate of rise will bring a high mortality even though the total rise is within the tolerance of the species. A rate of rise of 0.166 feet per day for 5 days damaged 40 per cent of the eggs in nests which were subjected to it. This total rise is less than half the value thought to be the maximum tolerance.

Falling water levels brought about a loss of Western grebe eggs, but this was thought to be due to isolation of the nest at a height beyond the reach of these aquatic birds.

There was no significant difference in brood survival between the three types of areas studied, and from this it is concluded that brood survival is not affected by fluctuating or falling water levels.

Waterfowl food plant production is decreased on areas of $f$ luctuating water levels by reason of the lack of submergent food plant species. Fmergent plants from the area with a fluctuating level produced more seed than the same species from an area with a stable level. This is contrary to the findings of other workers (Low and Bellrose, 1944). It is concluded that these emergent species produced more because they were alternately submerged and exposed. This action brings about soil aeration which is generally a limiting factor in marsh and aquatic plant growth.

Fluctuating water levels effect ecological changes that produce a less desirable habitat than is found on areas with stable water levels. For this reason and the fact that the nesting density was much lower than on an area with a stable level, it is concluded that areas with fluctuating levels discourage some waterfowl from nesting and they move to more favorable environments.

\section{SUMMARY}

1. A study was started in April, and continued through September, 1951 in order to determine the effects fluctuating and falling water levels had on waterfowl production. The investigations were carried out in Cache Valley which lies for the greater part in northern Utah but also extends into southern Idaho.

2. Three areas were selected for study. Swan Lake, an area in southern Idaho that has a stable water level, was selected as the control. Newton reservoir in Utah, which has a receding water level with a maximum fall of over 50 feet, was a problem area. It is an impoundment used for irrigation water storage and has a water level whi ch begins to fall in late May and

Department of Fisheries and Wildlife
Utah State University = UMC52
38 Logan, UT: 84322


continues to drop throughout the growing season. Cutler reservoir, an impoundment of the Bear River in Utah, has greatly fluctuating water levels and was also selected.

3. Whereas previous investigators have determined the extent of damage done by flood waters, this study intended to determine the total rise and rate of rise in relation to damage caused.

4. A nesting study was made wherein were observed the effects of different water levels on nesting waterfowl, a brood survival study was also made. A third phase was directed toward determining the effects of the various water levels on waterfowl food plant production.

5. Two areas of Cutler reservoir which were selected for study had a combined nesting density of one nest for each 3.39 acres, whereas there was one nest for each 0.575 acres on the control area of Swan Lake.

6. Eggs which failed to hatch were opened for examination and although mortality due to flooding was sometimes difficult to diagnose, the fact that undetermined causes accounted for 7 per cent of the eggs at Swan Lake and 10 per cent of the eggs on Cutler reservoir indicated a high validity and lack of prejudice in this diagnosis.

7. Direct damage to eggs by water was caused by partial or complete submergence. Indirect effects also were produced when water levels changed. Nests which were built up as the water rose generally were unstable when the water receded. These nests toppled and spilled eggs. Eggs were also spilled and buried when hens built up their nests to protect them from rising waters.

8. Coots were able to prevent di rect damage by rising water levels, but their nests suffered egg losses when water levels dropped. Most of the loss was attributed to toppling, but desertion was indicated when the level dropped 50 inches.

9. Thirty-one per cent of the potential waterfowl production on the Cutler reservoir areas was lost by flooding. Of this 94 per cent was confined to mallard and redhead nests. Fifty per cent of the mallard nests suffered partial or complete damage for a loss of 39 per cent of the mallard eggs. Ninety per cent of the redhead nests suffered loss to the extent of 46 per cent of potential production.

10. Mortality from flooding was caused throughout all stages of incubation and hatching.

11. Both mallards and redheads attempted to save their clutches by building on to the nest. Surrounding vegetation was closely cropped and used for material, but in spite of a generally exposed final condition, predation was absent.

12. Fifty per cent of the mallard nests were subjected to high water and 57 per cent of these were completely destroyed, but although 90 per 
cent of all redhead nests were subjected to flooding, there was not one instance of complete loss.

13. Typha sp. and Scirpus acutus, the two principal nesting materials, were tested for resistance to water-logging but no difference was found.

14. Some mallard nests escaped damage when the water level rose 0.83 and 1.92 feet but all were at least partially damaged by rises of 1.08 and 2.58 feet. About a two foot rise appeared to be the point of maximum tolerance for this species.

15. A rate of rise of 0.166 feet per day for 5 days damaged 53 per cent of the mallard nests so affected indicating that total rise is not the only factor involved.

16. Redhead nests were partially damaged by rises of 1.03 to 2.11 feet. A rate of rise of 0.166 feet per day for 5 days killed 40 per cent of the eggs in the affected redhead nests. A rate of rise of 0.293 feet for 3 days killed 77 per cent of the eggs in affected mallard nests.

17. The data obtained from the brood study indicated little or no difference in survival between the areas of falling, stable and fluctuating water levels.

18. The waterfowl food plant production study revealed a near-absence of submergent species in the Cutler reservoir areas with its fluctuating water levels.

19. Fmergent species on areas of fluctuating water levels produced more seed than the same species from the control area. 
Anderson, H. G.

1941 Studies Preliminary to a Waterfowl Restoration Program Along the Illinois River. Trans. Fifth No. Amer. Wildl. Conf. 369-373.

Bellrose, F. C. and Brown L. G.

1941 The Effect of Fluctuating Water Levels on the Muskrat Population of the Illinois River Valley. Journ. Wildl. Mgte. 5 (2): 206-212.

Craighead, F. C. and Craighead, J. J.

1949 Nesting Canada Geese on the Upper Snake River. Journ. Wildl. Mgte. 13 (1): 51-64.

Low, J. B. and Bellrose F. C. Jr.

1944 The Seed and Vegetative Yield of Waterfowl Food Plants in the Illinois River Valley. Journ. Wildl. Mgte. 8 (1): $7-22$.

Martin, A. C. and Uhler, F. M.

1939 Food of Game Ducks in the United States and Canada. U. S. D. A. Tec. Bull. \#643.

Wiebe, A. Ho and Hess, A. D.

1944 Mutual Interests of Wildlife Conservation and Malaria. Control on Impounded Waters. Journ. Wildl. Mgte. 8 $(4): 275-283$.

Wiebe, A. H.

1946 Improving Conditions for Migratory Waterfowl on TVA Impoundments. Journ. Wildl. Mgte. 10 ( 1 ): 4-8.

Williams, C. S. and Marshall, W. H.

1937 Goose Nesting Studies on Bear River Migratory Waterfowl Refuge. Journ. Wildl. Mgte. I (3): 77-86.

1938 Duck Nesting Studies, Bear River Migratory Bird Refuge. Journ. Wildl. Mgte. 2 (2): 29-48. 
A P P E N D X 
Appendix Table 1. SWAN IAKE WATER IEVEIS IN FEET ABOVE MEAN SEA LEVEI

\section{1}

\begin{tabular}{|c|c|c|c|c|}
\hline Date & April & May & June & July \\
\hline 1 & 4766.00 & 4765.50 & & \\
\hline 2 & & & 4765.854 & \\
\hline 3 & & 4765.417 & & \\
\hline $\begin{array}{l}4 \\
5\end{array}$ & & 4765.345 & & \\
\hline 6 & & & & 4764.625 \\
\hline 7 & & & & \\
\hline $\begin{array}{l}8 \\
9\end{array}$ & & & & \\
\hline 10 & & & & \\
\hline 11 & 4765.875 & 4765.25 & & \\
\hline $\begin{array}{l}12 \\
13\end{array}$ & & & 4765.187 & 1764.583 \\
\hline $\begin{array}{l}13 \\
14\end{array}$ & & 4765.354 & & $4(04.303$ \\
\hline 15 & & 4100034 & 4765.084 & \\
\hline 16 & 4765.782 & & & \\
\hline 17 & & & & \\
\hline $\begin{array}{l}18 \\
19\end{array}$ & & & 4764.917 & \\
\hline $\begin{array}{l}19 \\
20\end{array}$ & 4765.417 & & & \\
\hline 21 & & 4765.333 & & \\
\hline 22 & & 4765.333 & 4764.771 & 4765.021 \\
\hline 23 & 4765.292 & & & \\
\hline 24 & & & & \\
\hline $\begin{array}{l}25 \\
26\end{array}$ & & & & \\
\hline $\begin{array}{l}26 \\
27\end{array}$ & & 4765.313 & & \\
\hline $\begin{array}{l}27 \\
28\end{array}$ & 4765.375 & & & 4705.208 \\
\hline 29 & & & 4764.75 & \\
\hline 30 & & & & \\
\hline 31 & & & & \\
\hline
\end{tabular}


Appendix Table 2. NEWTON RESERVOIR WATER LEVELS IN FEET ABOVE MEAN SEA LEVEL

1951

April

4773.81

2

3

4

5

6

7

8

9

10

11

12

13

14

15

16

17

18

19

20

21

22

23

24

25

26

27

28

29

30

31

4774.39
May

$4774 \cdot 27$

4774.28

4774.28

4774.25

4774.23

4774.17
June

4774.00

4773.90

4772.63

4770.69

July

4762.3

4760.8

4760.8

4760.5

4766.1

4765.0

4760.2 
Appendix Table 3. CUTLER RESERVOIR WATER LEVEIS IN FEET ABOVE MEAN SEA LEVEL

Cache Junction, Utah, Gage

1951

\begin{tabular}{rrrrr} 
Date & Apri1 & May & June & July \\
\hline \hline 1 & 4404.53 & 4405.97 & 4406.99 & 4404.71 \\
2 & 4.29 & 5.95 & 6.98 & 4.85 \\
3 & 4.13 & 5.59 & 6.88 & 4.56 \\
4 & 4.19 & 5.24 & 6.30 & 5.36 \\
5 & 4.24 & 5.08 & 5.84 & 5.51 \\
6 & 4.26 & 4.85 & 5.78 & 5.51 \\
7 & 4.70 & 4.63 & 5.81 & 5.94 \\
8 & 5.29 & 4.69 & 5.95 & 6.50 \\
9 & 5.63 & 4.74 & 5.76 & 6.50 \\
10 & 5.68 & 7.76 & 5.87 & 6.39 \\
11 & 5.55 & 5.29 & 5.64 & 6.32 \\
12 & 5.52 & 5.62 & 5.41 & 6.30 \\
13 & 5.44 & 5.78 & 6.16 & 6.16 \\
14 & 5.19 & 6.11 & 5.71 & 5.87 \\
15 & 5.16 & 6.31 & 5.01 & 6.31 \\
16 & 5.14 & 6.38 & 4.97 & 6.47 \\
17 & 5.13 & 6.37 & 5.86 & 6.36 \\
18 & 5.12 & 6.31 & 5.49 & 6.36 \\
19 & 5.10 & 6.38 & 5.31 & 6.60 \\
20 & 5.10 & 6.43 & 5.57 & 6.59 \\
21 & 5.11 & 6.62 & 5.92 & 6.47 \\
22 & 5.13 & 6.75 & 5.81 & 6.91 \\
23 & 5.13 & 6.87 & 6.25 & 6.86 \\
24 & 5.06 & 7.06 & 6.42 & 6.75 \\
25 & 4.89 & 7.20 & 5.94 & 6.76 \\
26 & 5.27 & 7.31 & 5.65 & 6.81 \\
27 & 5.42 & 7.51 & 6.06 & 6.62 \\
28 & 5.52 & 7.70 & 5.47 & 6.42 \\
29 & 5.60 & 7.61 & 4.72 & 6.79 \\
30 & 4405.93 & 7.20 & 4407.04 & 6.69 \\
31 & & 4407.04 & & 4406.45
\end{tabular}


Appendix Table 4. CUTLER RESERVOIR WATER LEVEIS IN FEET ABOVE MEAN SEA LEVEL

Cache Junction, Utah Gage

\begin{tabular}{|c|c|c|c|c|}
\hline Date & April & May & June & July \\
\hline 1 & 4406.41 & 4405.89 & 4405.69 & 4406.03 \\
\hline 2 & 6.33 & 6.21 & 5.97 & 5.89 \\
\hline 3 & 6.30 & 6.03 & 6.25 & 5.99 \\
\hline 4 & 6.24 & 5.45 & 6.51 & 6.13 \\
\hline 5 & 6.16 & 5.35 & 6.53 & 6.21 \\
\hline 6 & 5.05 & 4.91 & 6.63 & 6.11 \\
\hline 7 & 4.54 & 5.53 & 6.53 & 5.99 \\
\hline 8 & 4.57 & 5.89 & 6.06 & 5.91 \\
\hline 9 & 4.53 & 6.33 & 6.19 & 5.7. \\
\hline 10 & 4.61 & 6.47 & 6.39 & 5.6 \\
\hline 11 & 5.03 & 6.37 & 6.91 & 5.79 \\
\hline 12 & 5.33 & 5.95 & 6.01 & 6.03 \\
\hline 13 & 5.33 & 6.31 & 5.93 & 6.2 \\
\hline 14 & 5.33 & 5.07 & 5.59 & 6.2 \\
\hline 15 & 5.65 & 4.75 & 5.57 & 6.11 \\
\hline 16 & 5.75 & 4.51 & 5.67 & 5.93 \\
\hline 17 & 6.13 & 4.11 & 5.81 & 5.96 \\
\hline 18 & 6.61 & 4.19 & 5.89 & 5.97 \\
\hline 19 & 6.95 & 5.59 & 6.07 & $5.9^{\prime}$ \\
\hline 20 & 6.79 & 5.29 & 6.25 & 6.0 \\
\hline 21 & 6.67 & 5.23 & 6.29 & 6.1 \\
\hline 22 & 6.13 & 5.15 & 6.21 & 6.2 \\
\hline 23 & 5.87 & 4.71 & 6.23 & 6.3 \\
\hline 24 & 5.41 & 5.27 & 6.47 & 6.4 \\
\hline 25 & 5.51 & 6.29 & 6.34 & 6.5 \\
\hline 26 & 5.57 & - & 6.27 & 6.65 \\
\hline 27 & 5.47 & 6.54 & 6.22 & 6.63 \\
\hline 28 & 5.47 & 6.18 & 5.09 & \\
\hline 29 & 5.73 & 6.33 & 6.20 & \\
\hline 30 & 4405.43 & 6.65 & 4406.29 & \\
\hline 31 & & & & \\
\hline
\end{tabular}

\begin{tabular}{|c|c|c|c|c|}
\hline Date & April & May & June & July \\
\hline 1 & 4405.11 & 4404.39 & 4405.67 & 4404.55 \\
\hline 2 & 4.81 & 4.39 & 5.25 & 4.43 \\
\hline 3 & 4.27 & 4.27 & 5.33 & 4.03 \\
\hline 4 & 5.11 & - & 5.85 & 4.63 \\
\hline 5 & 4.87 & -- & 5.23 & 4.91 \\
\hline 6 & 4.37 & -- & 5.57 & 4.67 \\
\hline 7 & 4.65 & -- & 5.61 & 4.31 \\
\hline 8 & 4.61 & $-\infty$ & 6.19 & 4.39 \\
\hline 9 & 3.99 & -- & 5.65 & 4.55 \\
\hline 10 & 3.69 & - & 5.67 & 4.83 \\
\hline 11 & 5.35 & - & 5.61 & 5.09 \\
\hline 12 & 5.43 & 5.55 & 5.09 & 5.51 \\
\hline 13 & 5.13 & 5.43 & 5.13 & 5.53 \\
\hline$u_{4}$ & 4.67 & 5.39 & 5.09 & 5.65 \\
\hline 15 & 4.03 & 5.25 & 4.75 & 5.81 \\
\hline 16 & $-\cdots$ & 5.27 & 4.79 & 5.97 \\
\hline 17 & 3.61 & 5.39 & 5.13 & 6.17 \\
\hline 18 & 4.53 & 5.27 & 5.31 & 6.19 \\
\hline 19 & 4.99 & 5.63 & 5.43 & 6.13 \\
\hline 20 & 4.95 & 5.93 & 5.49 & 6.07 \\
\hline 21 & 4.87 & - & 6.67 & 6.23 \\
\hline 22 & 4.93 & - & 5.37 & 5.97 \\
\hline 23 & 5.33 & $--\infty$ & 5.55 & 6.11 \\
\hline 24 & 5.59 & -- & 5.69 & 6.19 \\
\hline 25 & 5.71 & 6.81 & 5.57 & 6.49 \\
\hline 26 & 5.77 & 6.55 & 5.57 & 6.27 \\
\hline 27 & 5.57 & 6.39 & 5.63 & 6.19 \\
\hline 28 & 5.27 & 6.27 & 5.59 & 6.31 \\
\hline 29 & 4.89 & 6.15 & 5.09 & 6.71 \\
\hline 30 & 4404.43 & 6.01 & 4404.53 & 6.61 \\
\hline 31 & & 4405.77 & & 4406.27 \\
\hline
\end{tabular}


Appendix Table 5. SCIENTIFIC NAMES CF WATERFOWI

Common Name

Western Grebe

Pied-billed Grebe

Canada Goose

Conumon Mallard

American Pintail

Green-winged Teal

Blue-winged Teal

Cinnamon Teal

Shoveller

Redhead

Canvas-back

Lesser Scaup Duck

Ruddy Duck

American Coot
Scientific Name

Aechmophorus occidentalis

Podilymbus podiceps

Branta canadensis

Anas platyrhynchos platyrhynchos

Anas acuta tzitzihoa

Anas carolinensis

Anas dis cors

Anas cyanoptera cyanoptera

Spatula clypeata

Athya americana

Athya valisineria

Athya affinis

Oxyura jamaicensis rubida

Fulica americana 


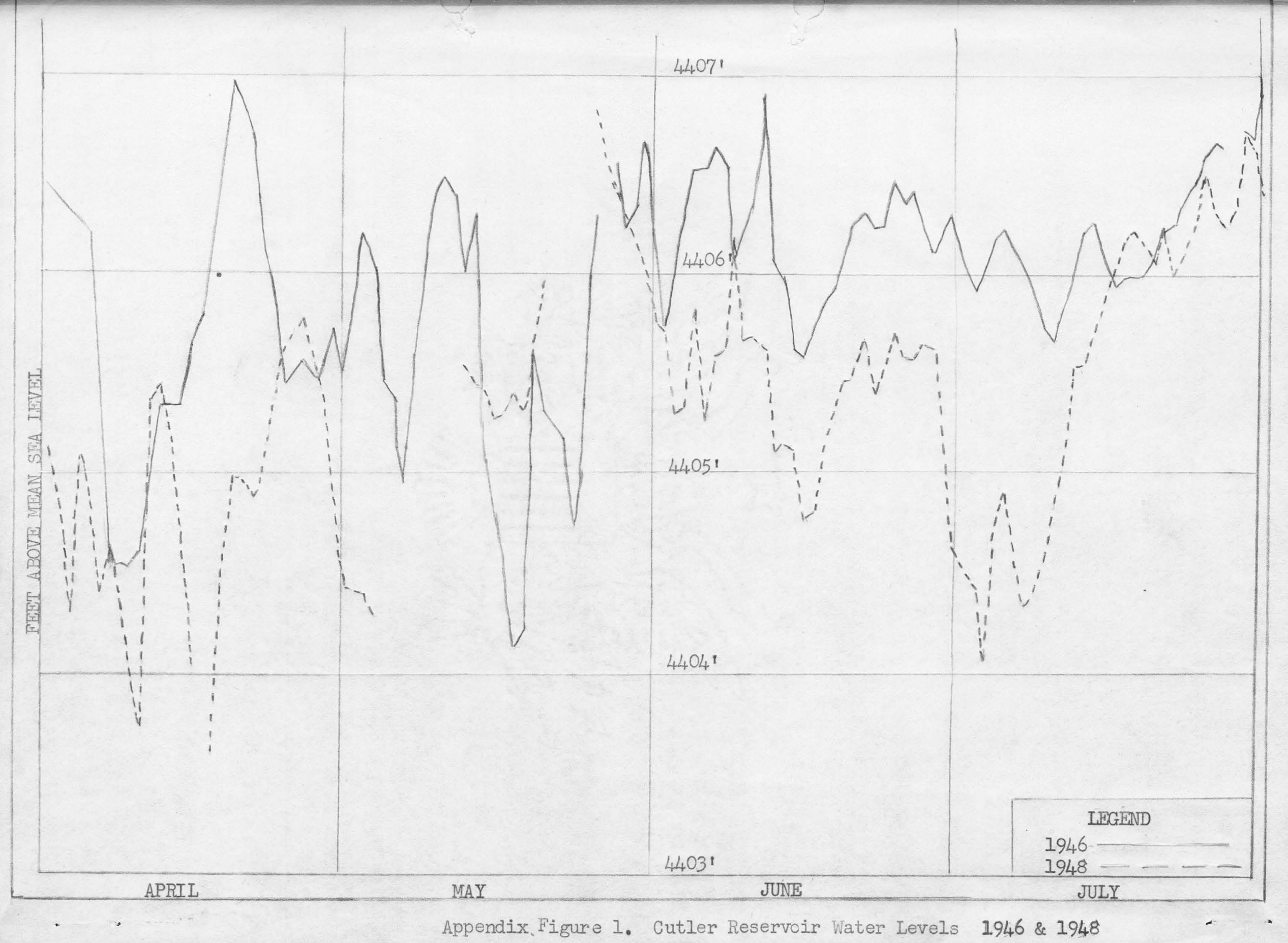


Reference No.

Species

Date Fours

No. Hatched

No. Unhatched

Corer

Predation Date

Abardoned Date

Destruction or. Injury Dàte

Distance from Flge Wâter
Unit No. Eggs

Date Hatched

Hatching Success

Reason

How Located

Canse

Cause

Cause

Shore

\begin{tabular}{|c|c|c|c|c|}
\hline \multirow[t]{7}{*}{ Revisits - Date } & $\begin{array}{l}\text { : Fgg Distance } \\
: \text { above iv atet }\end{array}$ & $\begin{array}{l}\text { Egg Djstance } \\
\text { : above ground }\end{array}$ & $\begin{array}{l}\text { : Water } \\
\text { : depth }\end{array}$ & $\begin{array}{l}\text { : Fige } \\
\text { : distance }\end{array}$ \\
\hline & $:$ & $:$ & $:$ & : \\
\hline & : & : & : & $:$ \\
\hline & : & $:$ & i & : \\
\hline & $\div$ & : & $:$ & $\therefore$ \\
\hline & : & $\vdots$ & $\vdots$ & $\begin{array}{l}\vdots \\
\vdots\end{array}$ \\
\hline & : & : & : & : \\
\hline \multirow{3}{*}{ 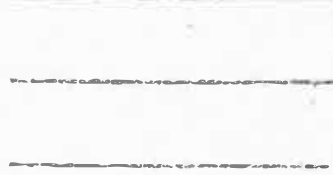 } & : & : & : & : \\
\hline & $:$ & : & : & : \\
\hline & : & : & : & $:$ \\
\hline \multirow{2}{*}{ 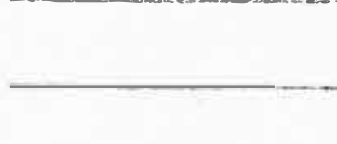 } & : & $:$ & $:$ & : \\
\hline & $:$ & $\therefore$ & $\therefore$ & $:$ \\
\hline \multirow{3}{*}{ 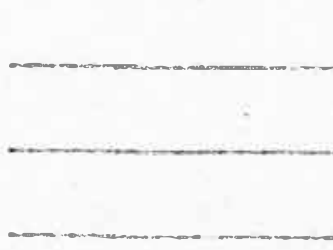 } & . & $\therefore$ & & \\
\hline & : & : & : & : \\
\hline & : & : & : & : \\
\hline \multirow{3}{*}{ Remarks. } & : & : & : & : \\
\hline & : & $i$ & : & : \\
\hline & : & : & : & : \\
\hline
\end{tabular}

